\title{
Metodología y cuestiones previas para el estudio de los Nacimientos españoles
}

\section{ESTADO DE LA CUESTIÓN}

La costumbre de poner o armar el belén o Nacimiento, usual en el ámbito católico, es, o ha sido hasta hace poco, una de las tradiciones más arraigadas de la religiosidad española. El fenómeno tiene además un marcado caracter popular, pues se trata, en realidad, de un acercamiento al pueblo cristiano para el mejor entendimiento de la liturgia, simultáneamente o a consecuencia de las representaciones del ciclo de la Navidad, fosilizadas en los llamados "belenes vivientes". A pesar de ello es notoria la escasez de estudios sistemáticos con validez científica, incluyendo trabajos de campo, que nos permitan un acercamiento a tan importante fenómeno. En el momento actual, la situación es particularmente grave porque, al igual que otros aspectos del mundo tradicional, corrientes surgidas a mediados del siglo XIX, procedentes tanto de ámbitos eclesiásticos como civiles, han arrasado casi por completo las peculiaridades del fenómeno, sustituyéndolas por otras actitudes religiosas o por rígidas reglamentaciones estéticas, como las normas de corte academicista -escala y perspectiva principalmente- fidelidad bistórica $y$ buen gusto, propiciadas por las Asociaciones de Belenistas.

Mientras, los orígenes, antecedentes, expansión, evolución y tipología del belén en nuestro país nos son prácticamente desconocidos, ya que la mayor parte de la bibliografía específica podría definirse como literatura sentimental cuando no como masa de datos donde suelen aparecer sin orden ni concierto rèferencias plásticas del ciclo de Navidad que poco tienen que ver con el belén. En otras publicaciones se intenta demostrar la pujanza de la producción local, deslizándose a menudo por la pendiente de las afirmaciones categóricas. Por último, existen una serie de lugares comunes que se consideran de obligada cita al tratar del tema.

Además, y salvo casos muy contados - los trabajos de Llompart y parte del material de Amades, de los que se tratará más adelante- los tratadistas españoles sobre el tema suelen centrarse en las figuras y sus autores, desdeñando el entorno, por ser efímero. 
Entiéndase que, a lo largo de este trabajo nos referiremos única y exclusivamente al belén como montaje específico para los días de Navidad, cuyas características y límites procuraremos fijar más abajo, fenómeno estacional, con todos sus componentes y tipos, que deseamos estudiar en su conjunto, por lo que se deja aparte la copiosa bibliografía acerca de las manifestaciones plásticas, pintura y escultura principalmente, referentes a la Natividad, así como los aspectos iconográficos e históricos que de ellas se derivan.

Muy pocos han intentado deducir la evolución, desde un punto de vista antropológico, del Nacimiento en la tradición española. Las referencias a los grandes o anónimos maestros y a los orígenes italianos del belén parecen preocupar más que definir las características básicas del fenómeno. La carencia de material dificulta el estudio, carencia producida por ciertas medidas políticas tomadas en el siglo pasado -especialmente la desamortización de Mendizábal - las guerras más recientes, el cambio de gustos y, por último, el aggiomamento de la Iglesia Católica.

La inaccesibilidad de los monasterios de clausura, último reducto del viejo arte belenístico-conventual, contribuye al desconocimiento de los escasos ejemplares que puedan restar, así como la consideración de "arte menor" de este tipo de conjuntos, normalmente de escaso valor material, que viene excluyéndolos de los catálogos monumentales e inventarios artísticos, incluso los más actuales.

\section{LA ESTETTCA DOMINANTE}

Joan Amades, en su obra El Pessebre, publicada en 1935, considera estéticamente inferiores las figuras murcianas a las catalanas, entre otras cosas por su colorido chillón, pero concede que, al copiar los modelos catalanes, los barristas murcianos perfeccionaron y mejoraron notablemente su producción '. Apreciaciones como la recogida son habituales en los trabajos sobre el tema, lo que evidencia un prejuicio ante el arte popular, al que se considera como imperfecto y torpe en su manifestación, defectos ambos que se intentarán corregir desde arriba, sirviendo los "entendidos" de guías estéticos y proponiendo las soluciones adecuadas.

Esta será una de las razones determinantes para el surgimiento de las Asociaciones Belenistas. Estas, siguiendo las normas del llamado buen gusto,

1 AMADEs, op. cit., p. 119.. .El tall de les figures murcianes és notablement inferior al de les catalanes; son mes bastes de forma i de conjunt ordinari i barroer i no tenen ni molt llunyanament l'aire de les figures nostres. En termes generals, els personatges són mes prims que els catalans en relació amb llur alçada. [...] ...els figuraires murcians han copiat $\mathrm{i}$ reproduit els tipus de les figures nostrades $\mathrm{i}$ així han perfeccionat i millorat notablement llur producció..... 
definirán las características que ha de tener un belén para que resulte aceptable. Así, la tradición es reprimida y erradicada en un lapso muy breve, creando un sentimiento social de vergüenza y sentido del ridículo ante su propio legado, presentado como un producto de ignorantes y niños frente a creaciones perfectamente acordes con la idea decimonónica de lo correcto. El mensaje final es claro: o se monta bien el belén, o es mejor no montarlo. Aquí vuelven a intervenir las Asociaciones, especialmente a través de los llamados Consejos artísticos, con asesores que dictaminan acerca de las diferentes calidades. Las producciones de Olot, por citar un ejemplo, vienen proponiéndose, desde el siglo pasado, como ideales para belenes parroquiales y casas burguesas. Inspiradas en la visión melíflua del arte sacro francés, el célebre estilo Saint Sulpice, propuesto por las casas de imaginería religiosa de esta calle parisiense y sus aledaños, fueron adoptadas por la nueva burguesía catalana, atenta, más que a las tradiciones compartidas con la Península, a todo lo que llegara del país vecino. Pero lo verdaderamente grave es que, mientras el pensamiento del siglo $\mathrm{xx}$ ha hecho un esfuerzo por comprender las artes primitivas y la producción popular, con sus distintos puntos de mira, no necesariamente mejores ni peores que el arte oficial, en el ámbito del asociacionismo belenístico, la mirada estética ha quedado congelada, como veremos en el análisis que, a modo de ejemplo, presentamos a continuación.

\section{LAS ASOCIACIONES BELENISTAS}

En una entrevista realizada en los años cincuenta a Manuel de Mora López, fundador en 1943, de la Asociación de Belenistas de Madrid ${ }^{2}$, este explicaba la finalidad de dicha Asociación en los siguentes términos:

-...Nuestra labor consiste en hacer propaganda e instalar nacimientos [...] No vaya a creerse que esta Asociación de Belenistas instala vulgares nacimientos [...] la veracidad en la indumentaria de las figuras y la más pura originalidad artesana son los dos cánones en que se fundamenta la Asociación. No queremos [...] la construcción en serie de figuras de nacimiento llenas de anacronismos; vamos a purificar todo esto y a enmendar las faltas de sentido histórico...

-...Hay gran rivalidad entre ellos (los socios) por reproducir con exactitud biblica no sólo paisajes y ambiente, sino escenas y leyendas plastificadas...

Aspira (añade el entrevistador) esta Asociación a desterrar o remediar al menos ese mal gusto tan arraigado, y conseguir de los fabricantes un poco más de seriedad $\mathrm{y}$ arte en sus producciones.

2 José Antonio GonZÁlez-MuNiz, .Una Asociación de belenistas protectora de la artesanía, Revista de las artes y los oficios (Madrid, 1951), núm. 53-54, pp. 30-33. 
Las pautas estéticas de la Asociación de Madrid aparecen claramente influenciadas por las más antiguas asociaciones catalanas, como la barcelonesa, fundada en 1863, que imparten reglas de naturalismo, perspectiva y fidelidad histórica entendida al modo de la época. Comentaristas diversos se encargan de mantener vivo el prestigio de estas asociaciones pioneras, responsables de la regulación, mediante normas académicas, de un fenómeno tradicional. Para dar idea del lenguaje y contenido de estos comentarios, tomemos el de Garrut para el libro El belén en España ${ }^{3}$ donde describe una técnica "revolucionaria" que denomina "escuela de Barcelona", cuyo descubridor en 1912 es Antonio Moliné, al que apoda "Newton del belenismo", y que consiste en el uso de la escayola para la representación plástica del escenario o paisaje, técnica que exige una presentación cerrada, con embocadura a modo de teatro, a fin de ocultar imperfecciones y situar al espectador en un punto de mira obligado. El comentarista insiste en que antes de tal evento "la técnica del Belén era precariam. $Y$ añade: $Y$ ha sido el paisaje el promotor idóneo y una de las ilusiones del belenista, cuando se ha sentido un tanto a imagen y semejanza del Creador, trazando caminos, levantando montañas o convirtiéndose en arquitecto.....

Dejando aparte el tema de si el uso de la escayola es verdaderamente una innovación, las Asociaciones de Belenistas citadas y las que sucesivamente se crearon, han sido fieles a las directrices estéticas expuestas, en lo que atañe a figuras y escenario. Tomemos como ejemplo las bases que publicó la Asociación Belenista de Madrid para los concursos de Nacimientos y de figuras en la campaña de Navidad 1992. En la base $2 .^{2}$ se califican los Nacimientos según su estilo, de acuerdo con la división tradicionalmente postulada por la Asociación, consistente en:

a) HISTÓRICOS - Los construídos con características de naturalidad plástica, fidelidad histórica, evocación bỉblica del ambiente de Palestina en la época del Señor ${ }^{4}$, hallándose dotados de natural paisaje, perspectiva y embocadura.

b) POPULARES TRADICIONALES.-Los que están realizados siguiendo la costumbre española con corcho rústico, papel, escoria, cepas, etc.

c) POPULARES ARTÍSTICOS.-Son los populares con embocadura, celaje en semicírculo, perspectiva, etc.

d) MODERNOS. - Los que estén concebidos y realizados con libertad de criterios.

Como se aprecia, la definición de los Nacimientos llamados "históricos" y los "populares artísticos", abunda en contradicciones e incoherencias. En la

\footnotetext{
3 Véase: M. GarruT, "La nueva técnica belenista: orígenes y su adaptación internacional, El Belén en España (Madrid, 1983), pp. 103-111.

- El subrayado es nuestro. Jesús de Nazareth nació en Judea. La denominación "Palestina", esto es, "Tierra de los Filisteos", se impuso por los romanos como un castigo más tras las revueltas que condujeron a la aniquilación del reino de Judea.
} 
base $5 .^{a}$ se especifica, además: "...La falta de fidelidad religiosa o buen gusto ${ }^{5}$...será motivo de descalificación.

En las bases del $\mathrm{X}$ Concurso de figuras de Nacimiento "Trofeo Comunidad de Madrid, se reflejan los criterios fundacionales en la base $2 .^{2}$ : -Las figuras que se pre-

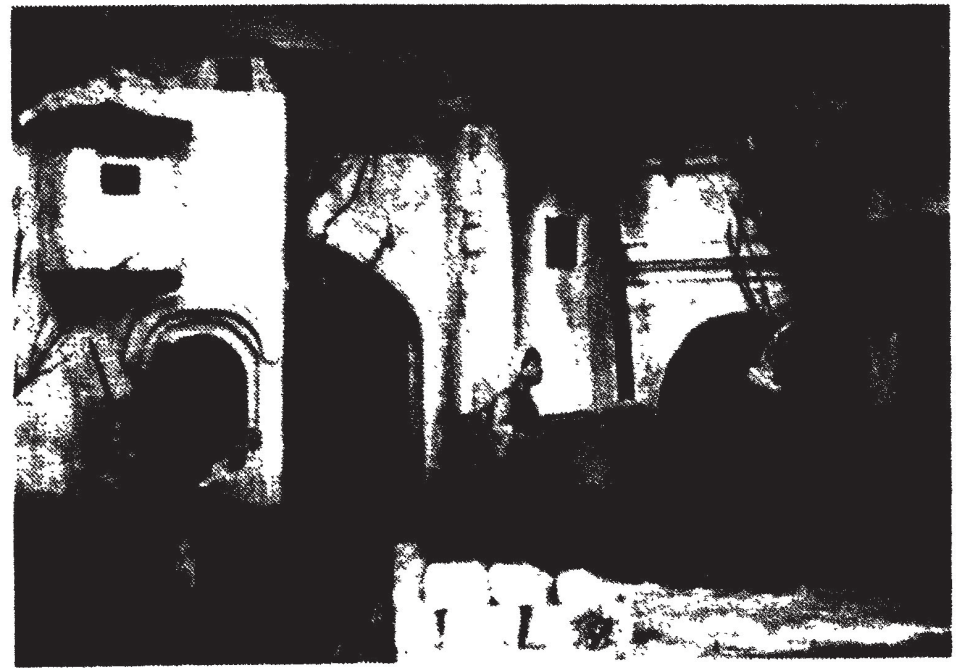
senten deberán ser originales, representando figuras clásicas de Nacimiento.

En el mismo año 1992, la Exposición "Descubre el belén", realizada por la Asociación Belenista de Madrid, e incluida en los actos correspondientes a la Capitalidad Europea de la Cultura, ofreció al público, desde la óptica de las Asociaciones de Belenistas, una panorámica de belenes completos, figuras y escenarios muy reveladora: los dos únicos ejemplos de "belenes populares" que se presentaron tenían embocadura, perspectiva y figuras a rigurosa escala.

Las figuras seleccionadas para representar la artesanía espanola actual eran todas de corte clasicista, inspiradas en modelos del pasado o en el orientalismo pictoricista del siglo XIx. El grueso de la Exposición, por último, estaba formado por los llamados dioramas, fruto de las directrices de la "escuela catalana" y el uso de la escayola al que aludía Garrut.

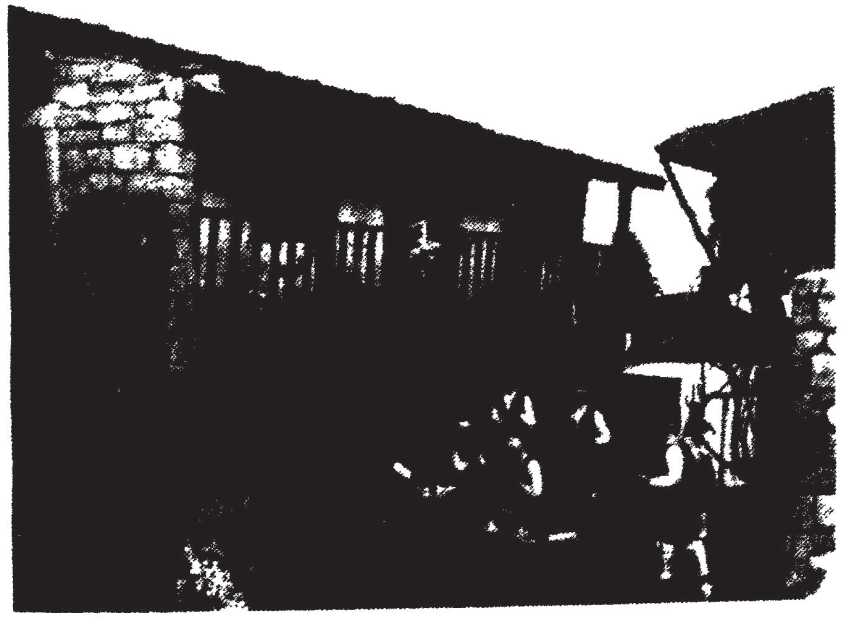

Agrupadas por la Asociación de Belenistas de Madrid, numerosas asociaciones del resto de España mostraron su total coincidencia en cuanto al objeto de su aficción: el diorama, a caballo entre los antiguos teatrinos y la maqueta a escala para adultos, única producción asociacionista presente en las salas.

El panorama es claro: la creatividad y libertad expresiva

LÁMS. I y II.-Ejemplares de dioramas de ambientación bíblica (I) y local (II). Asociación Belenista. Madrid, 1992. Fot. M. J. del Amo.

5 El subrayado es nuestro 
de los años sesenta y setenta ${ }^{6}$-que nunca agradó a las conservadoras Asociaciones de Belenistas - han quedado definitivamente atrás, sustituídas por modelos con pretensiones de corrección académica, más cercanos al eclecticismo (por no decir pastiche) que a las corrientes del siglo. Esta crisis es común a todo el arte sacro católico, pero en el mundo del belén, las preferencias del público, guiadas por las proposiciones de las Asociaciones de Belenistas, se inclinan al consumo de modelos conservadores. En cuanto al escenario, de nuevo son las Asociaciones catalanas las que dan el paso siguiente: tras la etapas de "fidelidad bíblica" y de "ambientación local", el diorama tiende a suprimir los personajes del drama sacro para representar, simplemente, ambientes, costumbres y efemérides locales que «ilustren" a los espectadores. A este respecto, un miembro de la Asociación de Pesebristas de Vic nos manifestaba en el XIV Congreso Internacional Belenista que el belén por el belén no tenía sentido, como dando a entender que esas maquetas anecdóticas, plenas de efectos escenográficos, con figuras realizadas de encargo, son el más allá del perfeccionismo belenista. De ser así, aparte del sentido de representación, no queda nada de las características definitorias de los Nacimientos españoles.

Vista la situación, pensamos que el papel futuro de las Asociaciones belenistas debería rebasar la mera construcción de Nacimientos según los modelos arriba expuestos, ya que es a estas agrupaciones, como promotoras de una vieja y arraigada costumbre, a quienes compete la responsabilidad de conocer y valorar dicha tradición, fijar su memoria antes de que esta se pierda irremediablemente $\mathrm{y}$, sobre todo, reconocer como especialistas el valor de aquellos belenes que, aunque se apartan de las normas académicas, representan una forma de ver el mundo en la que se encierran las claves y los porqués de una costumbre. Y, mientras persiste el desconocimiento actual de los planteamientos antropológicos del belenismo y su profunda razón de ser religiosa e histórica, sería deseable, al menos, que no se emitieran juicios de valor sustitutivos, proponiendo soluciones correctas ante usos populares.

\section{NECESIDAD DE UN PLANTEAMIENTO GENERAL}

Ante tal panorama, urge un estudio estructurado de los belenes españoles, que proporcione una visión real de lo que ha sido, verdaderamente, la

- El tema de la estética singular de los años 50 al 70, fué tratado en una exposición monográfica, que tuvo lugar del 23 de diciembre de 1991 al 6 de enero de 1992 en la sala de exposiciones de Caja España de Zamora, con parte de la Colección del Museo Nacional de Artes Decorativas. En el catálogo se realizó un análisis de sus orígenes y producción. Ver: Letizia ARBETETA MIRA, Belenes del Museo Nacional de Artes Decorativas (Zamora, 1991). 
tradición del Nacimiento o belén en Espana, y la relación que tuvo con el resto de la cristiandad, en sus vertientes religiosa, artística y antropológica, lo cual sólo será posible si se propone de antemano una metodología, con validez científica, que incluya el planteamiento de las cuestiones necesarias para el conocimiento de dicha tradición.

Creemos, en primer lugar, que dicha estructuración debería ser común para toda España, pues, hasta la fecha predomina la bibliografia localista que ignora o rechaza las lógicas influencias del entorno, aceptándolas, sin embargo de lugares más alejados, preferiblemente extranjeros, como si reconocer lo primero rebajara la originalidad de sus tradiciones locales.

Antropológicamente hablando, existen zonas fósiles, donde las tradiciones conservadas no son exclusivas del lugar, sino restos -las más de las vecesde usos y costumbres comunes a zonas más amplias.

Carecemos de trabajos de campo realizados acerca de la tradición belenista, Hubiera sido de muy valiosa ayuda contar con una encuesta acerca del belén, similar a las del Ateneo de Madrid, de principios de siglo, pues los datos que pudiéramos obtener actualmente no sobrepasarían las fechas de introducción del gusto academicista y dulzón propuesto por el París de la segunda mitad del siglo XIX.

Si se pudiera hacer un estudio de los pedidos, a lo largo de este siglo, de la producción a escala de los talleres de Olot, por ejemplo, sabrímos que estas eclécticas figuras, muy costosas para la economía de las parroquias rurales, han sustituído, en cada una de ellas, un belén tradicional con yuxtaposición de elementos y escalas, retirado por su incongruencia, en el que las figuras de valor artístico - si existieron- han podido enajenarse para sufragar los gastos, y las más sencillas acabar en el trastero.

\section{LO ARTÍSTICO Y LO POPULAR COMO CONCEPTOS ANTAGÓNICOS}

Desgraciadamente, el caso de España no es como los de Portugal, Francia, Centroeuropa y sobre todo Italia, donde, además de antiguos ejemplares, se conservan noticias del interés demostrado en tiempos pasados por los $\mathrm{Na}$ cimientos como tales. En España apenas se ha investigado en nuestros ricos, aunque mermados archivos, y parece existir un prejuicio ante el belén que, para los historiadores del Arte pertenece al folklore y al mundo popular, definitivamente despreciado por ciertos especialistas, quienes aún insisten en la vieja división entre artes mayores y artes menores, y, dentro de estas, la separación entre lo artístico y lo popular. Es muy frecuente, por tanto, admitir como artísticos los Nacimientos cortesanos, especialmente los napolitanos, incluyendo su escenario cuando este es obra de escenógrafos y artistas 
consagrados, mientras que se suelen estudiar las figuras aparte, desechando o soslayando su posible entorno, si estas son de mérito.

Resulta sintomático que casi ningún estudioso, en sus trabajos acerca de esta pequeña estatuaria, haya hecho el menor esfuerzo por indagar acerca de sus montajes originarios, de su entorno.

Esta metodología anticuada vuelve a poner de manifiesto que lo popular viene a considerarse como algo imperfecto en su torpeza, resultado de una inmadurez y no de otra forma de ver las cosas. Al respecto, y retomando el mundo belenista, leemos en Belén, el boletín de la Asociación de Belenistas de Madrid, opiniones como las que siguen:

Si en el diorama artístico, que representa un intento de máxima perfección en la realización de una escena de la infancia de Jesús, es necesario tener forzosamente muy en cuenta la perspectiva, la iluminación y la pintura, en todo belén popular, aún en el más modesto,es conveniente observar en el montaje unas normas, que sin quitarle expontaneidad (sic), lo hagan más agradable y armonioso. Entre estas normas la principal es la perspectiva... [...] $]^{7}$

Ya para terminar, os diré que en Palestina no nieva normalmente, luego el Nacimiento no debe tener ni nieve ni escarcha, por lo que nos sobran los nevados de harina y las escarchas de ácido bórico. Sí es admisible en un belén regional o moderno la nieve, si en la región nieva ${ }^{8}$.

Como puede apreciarse, resulta intolerable para ambos autores la carencia de normas académicas o de lógica -entendida esta en un sentido superficial- en la producción popular, que se rige, precisamente, por parámetros ajenos a lo propuesto. La descalificación de la tradición se hace en estos dos ejemplos evidente. Los belenistas, deslumbrados por obras tales como la producida por Daniel Rops, „De la vida cotidiana en Palestina en los tiempos de Jesús", entienden que, en todo caso, ha de reconstruirse el ambiente palestino, y que lo artístico difiere de lo popular únicamente en la perfección de la maqueta y figuras, y los materiales empleados: corcho y musgo para lo popular, escayola pintada para lo artístico, bajo la forma de diorama.

\section{EL PAPEL de la IGlesia CATÓlica}

Otro importante aspecto es el del drástico giro que el Concilio Vaticano II dió a la liturgia de la Iglesia Católica, apreciable en varios aspectos:

' Jorge Alfaro DEST, AArte y técnica del belén. La perspectiva del belén. en Belén, boletín núm. 2, segunda época, marzo 1990, p. 23. D. Jorge Alfaro Drest es médico y en 1992 ha sido nombrado "maestro Belenista", máxima distinción que otorga la Asociación, premio a una larga y destacada trayectoria en el mundo del belenismo.

8 José Luis Alfaro, AArte y técnica del belén. El belén popular, Belén, boletín de la Asociación de Belenistas de Madrid, núm. 1 segunda época (octubre 1989), p. 23. 
1. Intento de suprimir ciertas tradiciones que no se ajustaban a las normas estrictamente religiosas, sea por degeneración o fosilización, lo que afectó principalmente a las grandes tradiciones festivas populares (Epifanía, Semana Santa, Corpus Christi, etc.).

2. Propuesta de una simplificación que pretendió retomar a la sencillez de la Iglesia Primitiva, lo que abarcó tanto la estética visual, como el desarrollo de los ritos e incluso la música.

3. Renovación del equipo litúrgico para adap-

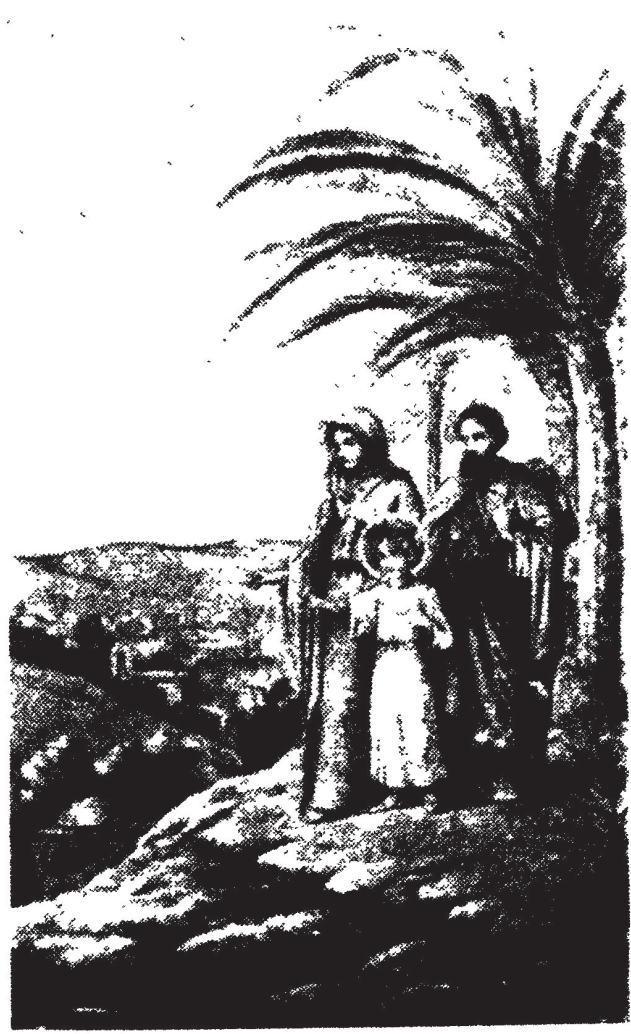
tarse a los modelos estéticos paleocristianos, en el lenguaje,

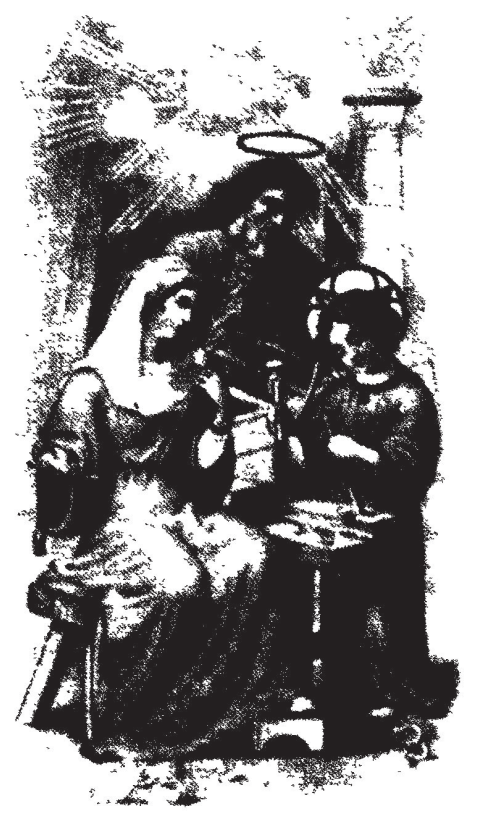
extremadamente discutible, de los años sesenta. El aspecto, y no la calidad, primaron en muchas ocasiones a causa de la prisa y la escasez de medios, utilizando materiales delcznables y diseños de infima categoría que sustituyeron a los anteriores".

4. Como resultado, algunas manifestaciones populares cayeron en desuso. En lo referente al belén, se acusa una fuerte inhibición ante los montajes complicados, y se propició, bien la exposición del Misterio o figuras básicas, bien la sustitución del Nacimiento por la presentación a los

LÁMS. III y IV.-Estampas devocionales basadas en modelos orientalistas. La lám. III corresponde al siglo xxx y la IV a la $1 .^{\star}$ mitad del xx.

9 La separación obligatoria de los altares adosados, a fin de poder celebrar la misa de cara a los fieles, solía traer aparejada una simplificación de la imaginería, desechando el exceso de estatuas y cuadros. Se retiraron lámparas, barandillas de separación de los presbiterios, gradillas y otros ornamentos que parecían excesivos, sustituyendo los viejos confesonarios, atriles y diversos muebles por otros con los símbolos de la iglesia primitiva; se inundaron los anticuarios de maderas doradas procedentes de viejos retablos, especialmente barrocos y populares del s. xvII, tenidos como de escaso valor y excesivo recargamiento; se dejaron de utilizar los ternos ricos y paños litúrgicos de textiles tradicionalmente estimados. La estudiada sencillez de la nueva estética prefería las telas burdas y lisas, con bordados muy simples y de gran tamaño. 
fieles del Niño Jesús en la cuna, devoción que, paradójicamente, está arraigada desde antiguo en algunas zonas peninsulares. Las Asociaciones Belenistas, sin embargo, reaccionaron ante tal situación presionando, con todos los medios a su alcance, para que se retornara a lo que ellos consideraban la tradición, lo que parcialmente han conseguido, siendo este su mayor mérito.

La Iglesia Católica tiene en todo momento un papel protagonista en el surgimiento y desarrollo del belenismo, pero, a lo largo de la segunda mitad del siglo $\mathrm{xx}$ se ha visto cómo los pocos restos de una antigua tradición eran retirados por vejestorios inadecuados en parroquias y conventos, lo que, unido a la actitud de estudiosos del tema, sociedades belenistas y coleccionistas acumulativos, que no selectivos, de figuras, dificulta extraordinariamente la localización de belenes tradicionales.

PROPUESTA DE UN SISTEMA METODOLÓGICO

Proponemos una relación de puntos básicos a considerar en la elaboración de futuros estudios sobre el belén. Este intento de sistematización, como es lógico, se irá perfeccionando con la práctica, y está sometido a continua revisión. A continuación se exponen, a modo de apuntes, temas y cuestiones más específicos.

A) Cuestiones Básicas

I. Antecedentes

II. Límites

a) Definición del belén

b) Características:

1. Formales (elementos imprescindibles, elementos secundarios)

2. Culturales ( ámbito cristiano-católico, representación visual de episodios de la vida de Jesucristo, escenario + personajes, mensaje)

3. Fenomenológicas (nacimiento de la costumbre, causas, elección de fecha, expansión, aceptación, usos,etc)

c) Ámbito de expansión

d) Cronología (de sus antecedentes, nacimiento y desarrollo)

III. Método de estudio

- Enfoque interdisciplinar:

a) Religioso 

b) Antropológico
c) Histórico
d) Artístico

IV. Fuentes

- Análisis crítico:
a) Historia de la Iglesia
b) Documentación eclesial
c) Documentación civil
d) Referencias contemporáneas
e) Bibliografía

f) Tradición oral

V. Estudio iconográfico
a) Cronológico
b) Geográfico
c) Religioso. Propuesta ortodoxa
d) Tradicional. Propuesta heterodoxa
e) Instrucciones
f) Correcciones
g) Prohibiciones
h) Bibliografía
i) Análisis de las fuentes
i) Análisis de los elementos

VI. Catalogación de los elementos materiales
a) Criterios selectivos de dichos elementos
b) Catalogación cronológica
c) Id. geográfica
d) Id. comparativa
e) Id. artística
f) Id. iconográfica

B) Cuestiones específicas para el estudio del belén en España

I. Antecedentes específicos

II. Análisis filológico

III. Encuadramiento dentro de la religiosidad tradicional.
a) Manifestaciones devocionales relacionadas con el belén, como el culto a Jesús: en la cuna, durmiente, infante, o actos institucionales (como la procesión del Corpus)
b) Otras representaciones del ciclo litúrgico con caracterís- ticas similares a las de los Nacimientos

IV. Ámbitos de implantación (eclesiásticos y civiles. Clases sociales)

V. Zonas de implantación geográfica 
VI. Influencias:
a) Internas: representaciones, tradiciones precristianas, localismos, etc.
b) Externas: Influencia de otros países cristianos. Actitudes de la Iglesia Católica en España. Otros

VII. Análisis crítico de los lugares comunes ( supuesto origen franciscano, lecturas culturalistas, alcance y realidad de la influencia italiana, etc.)

VIII. Establecimiento de una tipología del belén español:
a) Cronológica
b) Por zonas geográficas
c) El belén americano: diferenciación de los elementos autóctonos y los importados de España: arcaísmos y fosilizaciones

IX. Elementos propios
a) Materiales tradicionales
b) Diferencia de escalas
c) Sincronía
d) Representación nocturna
e) Repertorio visual. Frecuencia
f) Personajes específicos
g) Movilidad

$\mathrm{X}$. Actividades en torno al Nacimiento
a) Ritos y devociones de Adviento
b) Ofrendas (materiales, espirituales)
c) Representaciones dramatizadas
d) Música
e) Danza

XI. Historia:
a) El belén anterior a los Austrias
b) Los Austrias
c) Los Borbones
d) La influencia francesa a través de Cataluña
e) El siglo $\mathrm{XX}$

\section{DELIMTTACIÓN DEL ÁREA DE ESTUDIO}

La delimitación previa de los objetivos debería preceder a todo trabajo, pues conviene siempre comenzar con un correcto punto de mira. El problema se presenta cuando, siendo esta una cuestión preliminar, la definición de lo que son verdaderamente los belenes forma parte de las conclusiones, pues 
son la práctica y el conocimiento quienes propondrán las soluciones. Por tanto, abordamos el tema fijando límites provisionales, dejando para el final la revisión del ámbito belenístico.

El problema no es banal, ya que existe un gran desacuerdo entre los autores. La mayoría de las relaciones históricas del belén incluyen representaciones pictóricas y escultóricas relacionadas con la Natividad,-que conviven con lo que podríamos considerar específicamente como Nacimientos. Estos, a su vez, raramente se estudian como tales, sino que suele entresacarse alguno de sus elementos -especialmente las figuras-.

En la presentación de una obra publicada en 1968 bajo la dirección de los Boroli, dedicada al Nacimiento en Italia ${ }^{10}$, Luciano Zeppegno precisaba:

...se ha dado la preferencia a las obras de carácter popular, los auténticos belenes, los que, con figuras movibles por lo general, se montan en particular por Navidades; y también aquellos siempre estables, tradicional o documentalmente, conservados en iglesias y museos.

En esta breve definición se hacía referencia a la cualidad popular de los belenes, a su escenografía cambiante y estacional. En el caso de los montajes fijos, el Nacimiento se distinguiría por sí mismo del resto de las representaciones sacras, sobre todo por su mayor fragilidad, a causa de lo efímero de los materiales empleados en su montaje. La obra incluyó, asimismo, cualquier otro trabajo que pudiera influenciar al belén en su evolución, para poder explicar así el porqué de determinadas características.

Los principales tratadistas del tema coinciden en que es el conjunto de las figuras y su entorno lo que ha ido creando la costumbre belenística, cuya mejor definición es la castellana de altarcico de Pascuas", en definitiva la representación visual del misterio de la Encarnación.

El belén -como ya indicamos en un estudio anterior "- *...no sólo está compuesto por unas figuras de determinadas características, sino también de su escenografía, del entorno o paisaje donde han sido ubicadas. La posibilidad de que ciertas figuras hayan podido utilizarse para formar parte de uno de estos conjuntos es lo que hace incluírlas en un tratamiento belenístico.

\section{CARACTERÍSTICAS GENERALES DEL BELÉN}

En principio, admitimos que se trata de una representación tridimensional del nacimiento de Cristo, lo que excluye las representaciones pictóricas y

10 Ver Luciano ZEPPEGNO, Presepi artistici e popolari (Novara, 1968).

1 Letizia ARBeteta Mira, Apéndice: La exposición "Descubre el Belén", El Belén. bistoria, tradición y actualidad (Madrid, 1992), pp. 164-65. 
bajorrelieves, decantándose -en cuanto a figuras se refiere- por la escultura de altorrelieve y bulto redondo, aunque pueda incluir figuras recortadas, si se colocan con la intención de simular distintos planos. Esto supone que el belén nacerá como tal, independientemente de las representaciones teatrales, en época avanzada, una vez la Iglesia haya superado su reticencia inicial a la representación pictórica y escultórica de los personajes sagrados.

Otro elemento sería su movilidad, lo que no implica para incluír como belenes aquellas representaciones espaciales o tridimensionales que, aunque fijadas a un soporte, se hayan realizado empleando elementos que se concibieron, en origen, como móviles. Y, como en toda representación, son necesarios personajes: un símbolo, por muy completo que fuera, nunca constituiría un belén por si sólo.

Respecto a los personajes, cabe una división entre aquellos que resultan imprescindibles y los que podríamos llamar secundarios. Los primeros no podrían faltar en el Nacimiento sin que este perdiera su carácter de tal. Los segundos pueden aparecer o no, dependiendo del tipo de representación de que se trate. Pero esta división, no es fácil de establecer con carácter general, puesto que varía según las épocas, y es necesario apoyarse en un análisis iconográfico previo.

LOS PERSONAJES

\section{Personajes principales}

\section{Jesús}

En cuanto a los personajes imprescindibles, parecen los principales aquellos centrales del drama sacro: Jesús, María y José. Esto es cierto en líneas generales, aunque hay que matizar. El caso de Jesús es el único que está claro. Sin Él no habría belén. Se le representa recién nacido, algo crecido, e incluso infante, sobre el establo, una cuna, las pajas esparcidas, o el manto doblado de su Madre. Indefenso, vulnerable, fajado o desnudo. Las tradiciones basadas en el milagro de la misa de Greccio (Italia), acaecido en el año 1223 y recogido por Tomaso di Celano, relacionan el origen del belén con una representación visual (un pesebre, una mula y un buey vivos), con la que Francisco de Asís pretendía ambientar la celebración, a cargo del Cardenal Ugolino dei Conti di Segni. La visión sobrenatural del Niño Jesús en los brazos del Santo ciertamente generalizó, si no creó, el uso del belén. La Orden Franciscana tiene a gala el haber propagado tal devoción, y es posible, sin embargo, que el culto al Divino Infante instaurado por Santa Clara sí sea el origen de devociones tan peculiares como los repós de Jesús, o la más 


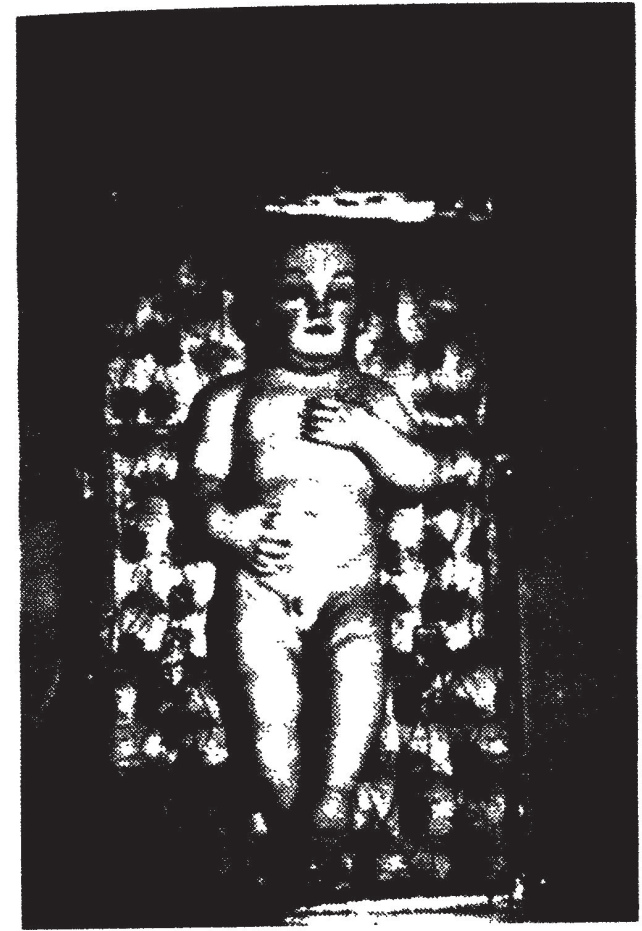

LÁM. V.-Niño Jesús en la cuna, s. XVIII. Salamanca (Exposición de Belenes Conventuales...).

Fot. A. Cea. difundida en España de los Niños Jesüs, indispensable en la mayoría de los conventos. ¿Puede la representación del Niño Jesús en la cuna, ser un belén por sí misma, o bien necesita otros elementos? A nuestro juicio sí, sean estos del tipo que sean, y al afirmar esto, nos remitimos a lo que más adelante se comenta, especialmente la visión iconográfica, bajo la que se irán estudiando las distintas representaciones de la Natividad y los personajes que en cada una de ellas proporcionan, con su presencia, lecturas diferentes. Las tradiciones basadas en los textos canónicos y apócrifos que relatan el nacimiento de Jesús exigen la presencia de todo tipo de figuraciones, desde las Personas de la Trinidad hasta los animales que moraban en el establo, elegidos por su valor simbólico.

\section{La Trinidad}

La representación de la Trinidad parece una constante en el belén español posterior al Concilio de Trento. Si analizamos el decano de nuestros nacimientos, el Betlem d'es Jesus, aunque aparece ya la paloma que representa al Espíritu Santo en los goigs o gozos del s. XIX, no se encuentra en el cuadro inspirado en este mismo belén, mucho más antiguo ${ }^{12}$. Tampoco aparece en los más antiguos belenes-gruta italianos, como los de Matera, Altamura, Cassano delle Murghe, etc., emparentados con este célebre de Palma de Mallorca. La tradición belenista italiana se decanta, sin embargo por la representación de los ángeles en adoración, como representantes del mundo superior. Sin embargo, la iconografía aparece claramente fijada en los bajorrelieves del s. XVI, como en la obra de Giovanni della Robbia, especialmente el retablo conservado en el Bargello de Florencia, cuya concepción está muy

12 Fue publicado por Llompart en un intento de demostrar su vinculación con los belenes-gruta italianos, y para proponer este montaje como iniciador de una tradición en la isla. En efecto, la disposición general de este tipo de belenes es la misma, y en todas falta una representación de las Personas celestes de la Trinidad. Ver G. LLOMPART, •Belenes conventuales mallorquines de los siglos XVII y XVIII, R.D.T.P., XXVI (1970), Cuadernos $1 .{ }^{\circ}$ y $2 .^{\circ}$, p. 45. 


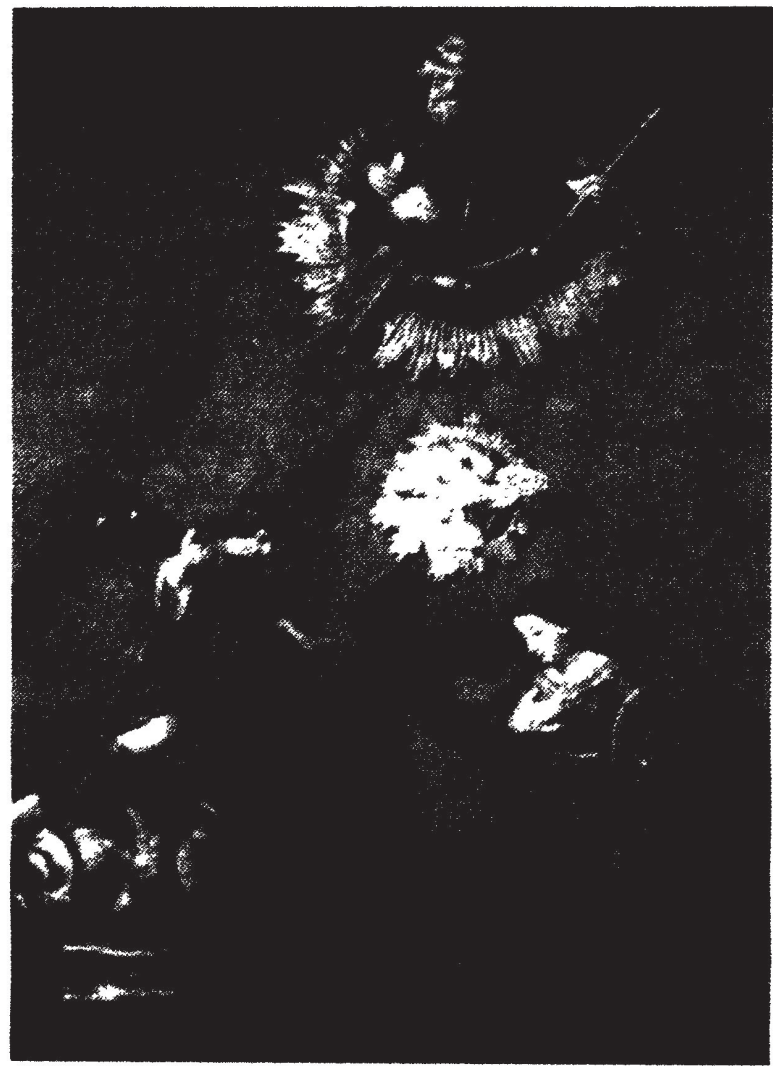

LÁM. VI.-Anunciación con el Padre Eterno.

Barro, pasta y enlienzado. S. xvir. (Col. part.). Fot. L. Arbeteta.

próxima a la representación móvil de los verdaderos belenes. Otras representaciones, como la que Francisco Grassia realizó para la iglesia de los Santos Alfonso y Tomás de Villanueva, en Roma, conceden mayor importancia al Padre Eterno, pero, mientras, la tradición popular italiana le ignora. En la pintura española, al igual que la de otros países, la presencia de la Trinidad se representa en las siguentes escenas: Anunciación; Natividad; Bautismo de Cristo y Crucifixión, que vienen a ser algunos de los puntos más relevantes de la vida de Cristo. Volviendo a Mallorca, resulta curioso que la representación del Espíritu Santo, y, a veces el Padre Eterno, son altamente populares y no pueden faltar de ningún belén Mallorquín, constituyendo la parte "celeste" del Nacimiento, llamada popularmente "la Gloria". Dejando aparte el hecho de que la paloma simboliza, asimismo, la vieja y profunda noción de la Shejiná, o Presencia Divina, llamada también La Gloria de Dios-concepto que aparece repetidamente en los textos bíblicos- lo que importa aquí es que tal tradición existe en la Isla con independencia del belén de Jesús, que influyó en el modelo cueviforme de montaje, pero que, a su vez. incorporó en fecha relativamente tardía (posiblemente el siglo XviI), la presencia de las figuras trinitarias. En la Península, sin embargo, la presencia de figuras móviles del Padre Eterno se documenta con ejemplos físicos desde 1650 aproximadamente, fecha atribuida a unas fi-

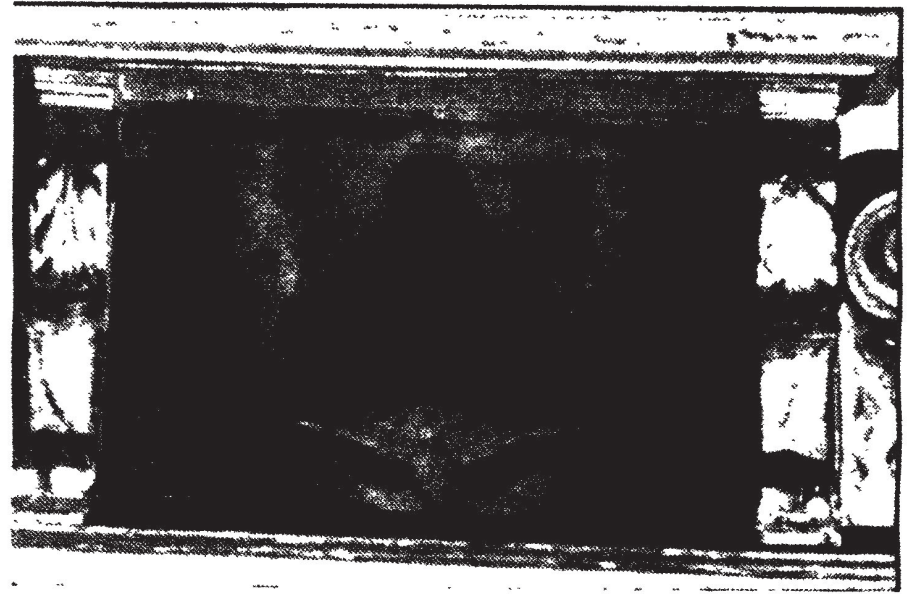

LÁM. VII.-El Padre Eterno y el Espíritu Santo. Ss. XVI-XVII. Óleo sobre tabla. Ático del retablillo de la Infancia de Jesús. Parroquial de Miranda del Castañar (Salamanca). Fot. A. Cea. 
guras de propiedad particular que se publican aquí por primera vez, correspondientes a una escena de la Anunciación, y que, además de la ya citada del Padre Eterno, incluye el Arcángel Gabriel, María y la Paloma del Espíritu Santo, en actitudes y plástica muy similar a las grandes interpretaciónes pictóricas que, sobre el mismo tema, trataron los pintores de la llamada Escuela Madrileña, a mediados del s. XVII.

La representación del Padre Eterno que presentamos en primicia, es de barro cocido y policromado, así como el enlienzado que simula las vestiduras. Su iconografía tiene raíces medievales, especialmente hispano-flamencas: Dios Padre, anciano de canosa y larga barba, aparece nimbado por el triángulo. Está representado de medio cuerpo, surgiendo de entre las nubes y rodeado por haz circular de rayos; su túnica azul contrasta con el manto rojo, con bordes dorados. En la mano derecha sujeta un memorial (?), apoyándose sobre el globo terráqueo, de gran tamaño y rematado por una cruz. Esta es, por el momento, la representación móvil de pequeña estatuaria de uso devocional o belenístico más antigua que conocemos, aunque seguramente posterior a muchas otras conservadas en montajes monacales de los que no tenemos noticia ni posibilidad de acceso. Pero sí puede damos idea de lo tradicional de tal representación un pinjante devocional existente en una colección particular, que contiene Natividad y Epifanía en relicario abridero, escenas minuciosamente talladas en marfil y policromadas que recuerdan posteriores trabajos quiteños. Esta pieza que, por su estilo, puede datarse en el s. XVI, muestra una figura de Dios Padre muy similar, con el Espíritu Santo debajo, flotando sobre el Niño Jesús al que adoran sus padres. Un ángel con cáliz y cruz en las manos, surge tras el otero, recordando el final de la ${ }^{13}$ obra de Cristo.

Por supuesto, documentación de referencia existe desde fecha muy anterior. En una loa valenciana del s. XV, citada por Amades ${ }^{14}$ el escenario tenía, además del Misterio, sibilas y profetas. Todas las figuras estaban vestidas con gran riqueza. Ante estas, los actores evolucionaban. La escena estaba muy iluminada por numerosos cirios. Enfrente se situaban Adán y Eva, el árbol del Paraíso con la serpiente y el Niño Jesús encima. En lo alto, niños vestidos de ángeles escoltaban con velas encendidas una representación del Padre Eterno, posiblemente similar a la máscara de cartón que se usa para tal fin en el convento de las M. M. Franciscanas Clarisas de Zamora, descrita por Cea Gutiérrez.

Es general,sin embargo, la tendencia que se aprecia en toda la Península, tanto en España como Portugal, de representar una zona celestial en el belén, lo que convierte a este en una teofanía, alcanzando un sentido de plenitud mística, asunto evidente en algunos aspectos, como se verá en el caso de los ángeles.

\footnotetext{
13 Véase V.V.A.A., Orfebreria de los siglos XV y xVI (Barcelona, 1989), p. 57.

14 Joan AMADES, op. cit.
} 


\section{Los ángeles}

El tema de la caída de los ángeles a causa de los celos de estos por la relación de Dios con el Hombre, inferior en su naturaleza, viene ya recogido por la tradición judía. En el cristianismo, las cosas ván más lejos, pues es Dios mismo quien se encarna y vive entre la Humanidad. Por tanto, la Adoración y acatamiento de los ángeles adquiere un alto valor místico, como reconocimiento por los mundos superiores de la íntima ligazón de Dios con lo humano. Los ángeles tañedores de instrumentos significan los coros celestiales, así como los volanderos que pueblan el cielo. Estos grupos representan a toda la masa angélica, que al unísono adora al Recién Nacido. Conviene diferenciar, pues, a los ángeles adorantes de los ángeles mensajeros de las diferentes embajadas (María, José, Pastores, Magos) de cada escena del ciclo. Este cuadro es continuamente representado en los primeros Nacimientos móviles de los que restan testimonios materiales, como las obras de los Alamanno en Nápoles y el conjunto de Mallorca, a ellos atribuido, así como en los belenes-gruta, donde cobra protagonismo al ocupar el primer plano, mientras que los pastores evolucionan sobre la montaña que sirve de techo a la cueva. La Adoración de los ángeles procedente del antiguo retablo de Nuestra Señora de Belén de Cifuentes (Guadalajara), hoy en la parroquia del Salvador, aunque esculpida en un solo bloque, consta haberse desmontado del retablo para

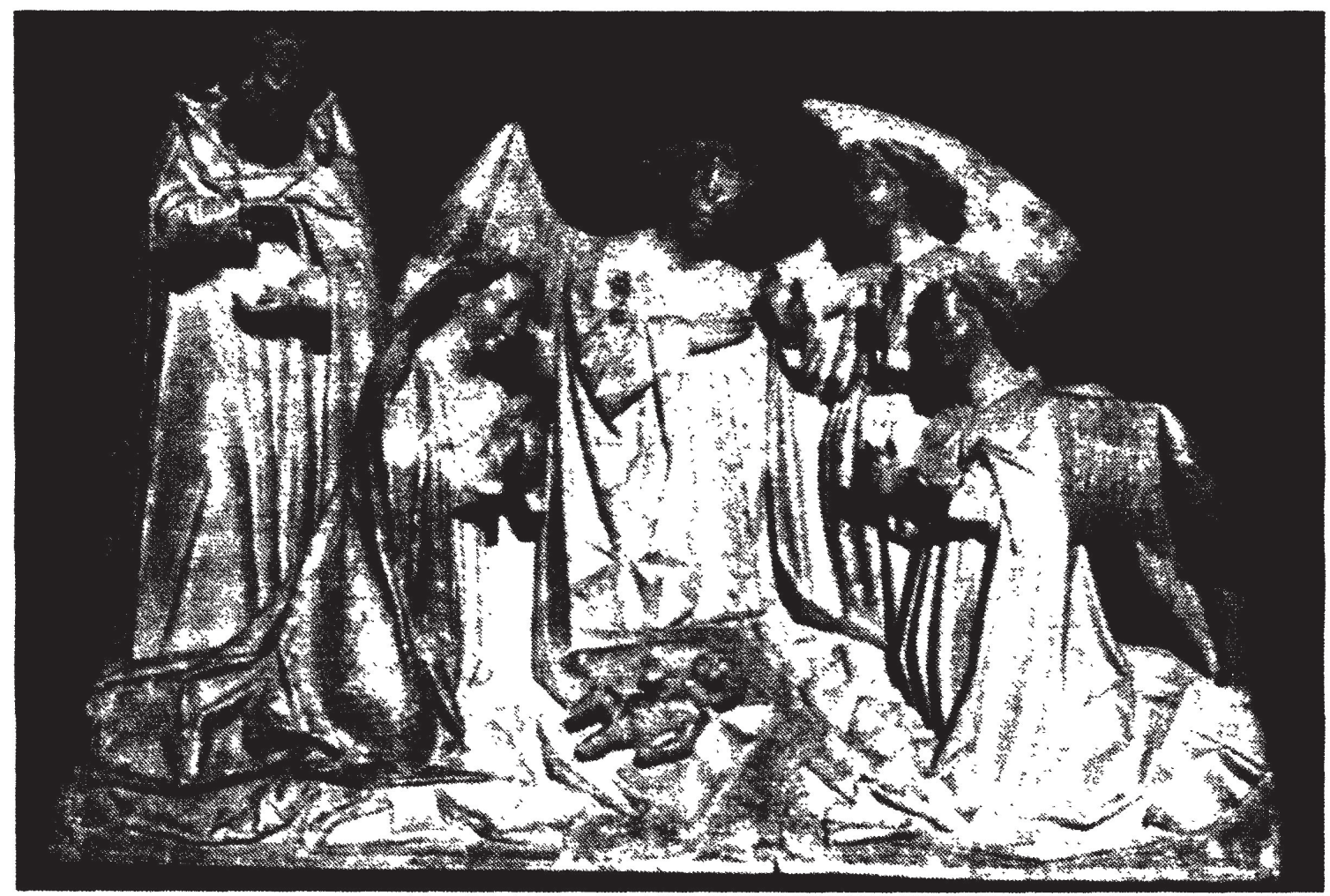

LÁM. VIII.-Adoración de los ángeles. Grupo del retablo de N.. S. de Belén (Madera dorada y policromada, s. Xv). Parroquial de San Salvador de Cifuentes (Guadalajara). 
ser enramada en época de Navidad, rodeada por diversas figuras, constituyendo un belén que coincide con las representaciones más antiguas, que incluyen también a los padres de Jesús, José de pie, alumbrando con la vela, María orante ante el Niño desnudo entre los pliegues de su manto ${ }^{15}$.

\section{La mula y el buey}

En las representaciones medievales del Nacimiento tuvieron gran protagonismo dos personajes hoy prácticamente relegados, la mula y el buey, hasta el punto de sustituir, en ocasiones, a los padres de Jesús. Ferreira de Almeida opina que es precisamente la presencia de los animales la que distingue el nacimiento de Jesús del de otros personajes, como la Virgen María o Juan el Bautista ${ }^{16}$. La creencia de que Cristo, como Mesías, habría cumplido todas las profecías, produjo comentarios como el de Orígenes, quien interpretaba la profecía de Isaías "El buey reconocerá su dueño y el asno el pesebre de su Señor" como una premonición del nacimiento de Jesús en el establo. Por tanto, los animales, sugeridos en un principio por su valor simbólico, pasarían, con el tiempo,a ser considerados como testigos de la venida al mundo del Cristo. Posteriormente, se les devolvería su valor simbólico. San Ambrosio, San Gregorio, San Jerónimo y, muy posteriormente, Rábano Mauro, vienen a identificar a ambos animales, ora con la gentilidad (el buey Apis, el Becerro de Oro), ora con el pueblo judío (primeramente el buey, sujeto por el yugo de la Ley, después se transfiere al asno, Ivrit, Yehudim). De hecho, en el siglo Iv, el cristianismo tiende a separarse cla-

15 Según testimonio de D. Benjamín Arbeteta Lope, natural de Cifuentes, nacido en 1919, recogido en 1992. El retablo -obra de fuerte influencia nórdica, realizado hacia finales del s. XV, con policromía posterior, del s. XVI-, ha sido publicado y estudiado en repetidas ocasiones por Layna Serrano, quien lo vincula a la fundación por Fernando de Silva, hacia 1527, del Monasterio de monjas franciscanas de Nuestra Señora de Belén. Constaba de imagen titular, hoy desaparecida, y una serie de escenas de la vida de María: Anunciación, Desposorios, Adoración de los ángeles, Epifanía y Circuncisión. Los grupos, mutilados a causa de la Guerra Civil, se han restaurado recientemente en el Instituto Central de Restauración de Bienes Culturales, y han formado parte de la exposición -Reyes y Mecenas* (Toledo, 1991). Fernando de Silva fué embajador en Roma y proveyó para la nueva casa moblaje, ropas y objetos de culto, todo de gran riqueza y costo. (Pedro de Salazar, Crónica de la provincia de Castilla en la Orden de San Francisco (1602), citado por F. LAYNA SERRANO, en su Historia de la Villa condal de Cifuentes (Guadalajara, 1978), pp. 130, 133. Ils. del retablo en láms. IX, X y XI).

16 C. A. Ferreira DE AlmeIDA, O Presepio na arte medieval, Revista Arqueológica (Porto, 1983), p. 16, nota 5. Agradecemos a la Dra. D. Ángela Franco sus interesantes noticias sobre este y otros estudios sobre la iconografía medieval. 
ramente del judaísmo, una vez nutrido de gentiles y rechazado por la mayoría del pueblo judío, entre otras razones, por no respetar el Pacto de Abrabam, esto es, la circuncisión. Por tanto, los gentiles que han visto la luz son altamente considerados, mientras que los judíos son tratados desde entonces como pertinaces en el error y doblemente despreciables, como es despreciada la caballería de ínfimo grado. De hecho, la presencia humillante del asno se acentúa en las ejecuciones o en los paseos punitivos, vuelto el reo de espaldas y sujetando el rabo del animal con las manos. Ferreira de Almeida publica en su trabajo una miniatura del Hortus Deliciarum, códice de hacia 1180 , en el que se puede apreciar claramente la relación del mundo judío con el burro, pues se trata de una Crucifixión ante la que aparecen la Iglesia Triunfante montada sobre un animal tetramórfico, y la Sinagoga, velada, sobre un asno, con la leyenda animal sinagogae asinus stultus et laxus" ${ }^{17}$. Debe recordarse que, para los judíos, el asno es un animal impuro y que, por tanto, su mera relación resulta humillante. La actitud de ambos animales en el pesebre pronto reflejará esa dualidad: mientras que el buey calienta con su aliento al recién nacido, la mula mordisquea las pajas, dá la espalda a Jesús, e incluso, como puede apreciarse en la miniatura dedicada a la Natividad en la Grand e General Estoria, de Alfonso X el Sabio, rey de Castilla, la mula o asno, con gesto maligno, muerde al propio Niño, indefenso y fajado. Aunque la actitud de señalar la mula como maliciosa y glotona, que come las pajas del pesebre para privar al Niño de colchón y abrigo, no es general dentro de las representaciones españolas, algunos artistas la tienen presente, con una constancia que indica intencionalidad, máxime si se circunscribe a la misma zona y época. En tablas atribuídas al Maestro de Paredes y al de Palanquinos, conservadas en el Palacio Episcopal de Palencia, encontramos a la mula con briznas en la boca, mientras que el buey no las tiene. En otra tabla de Juan de Flandes, la mula olisquea un haz de heno, mientras que el buey contempla la Epifanía ${ }^{18}$. Ejemplos similares pueden encontrarse en la escuela burgalesa del s. XV.

Sin embargo, el peso de la tradición paleocristiana, que otorgaba un papel inverso a los animales pesa todavía en San Bernardo, en Pseudo-Buenaventura y la Leyenda aúrea, donde se identifica la caballería del pesebre como la misma que conduce a María en la Huída a Egipto. En España, la presentación de la mula enjaezada, quizás como exculpación de su actitud negativa y su voracidad, es un rasgo arcaizante que es frecuente encontrar en grupos de belenes antiguos, como el de las Agustinas de Monterrey de Salamanca,

17 Ferreira de Almeida, op. cit., pp. 4-6, y en la página 6, fig. 2.

18 Ver A. SANCho CAMPo, La navidad en el arte palentino, vol. II (Palencia, 1971), láms. 101, 102, 104, 105. 
el descubierto y publicado por A. Cea en el monasterio de las Clarisas de Zamora ${ }^{19}$, o los descritos en los trabajos del Padre Llompart. Por otra parte, también es cierto que en numerosas representaciones medievales de la Natividad, especialmente las tardías, como las de la escuela flamenca e hispano-flamenca del siglo $\mathrm{XV}$, los animales pasan a un plano secundario, y no se advierte en ellos rasgo distintivo alguno.

\section{María}

La madre virginal de Jesús representa nada menos que al ser humano en el que se encarna el Dios Vivo. Por tanto, su figura capital, exaltada en la tradición medieval, es lógico que tenga el máximo rango en la representación de la Natividad. María-ostensorio, María-Trono del infante son figuraciones presentes en el mundo paleocristiano y bizantino, potenciadas en la escena de la Epifanía. En las representaciones medievales, recién nacido Jesús, María aparece recostada, descansando tras el esfuerzo del parto, tal y como puede verse en una pintura del siglo XIII procedente de Sagars, hoy en el Museo diocesano de Solsona, donde aparece vuelta de espaldas a su Hijo, arropado entre el buey y la mula. José a su lado, vela sentado ${ }^{20}$. La evolución de la doctrina de los Padres de la Iglesia en cuanto a la naturaleza del parto sobrenatural de María, que continúa siendo doncella, obliga a obviar sus circunstancias biológicas, y, para indicarlo de una forma visual, María ya no aparece recostada, sino sentada u orante, adorando al recién nacido que reposa sobre el suelo, las pajas o los pliegues de su manto. A este respecto, resulta importantísimo matizar el papel que, tanto el mundo judío como, posteriormente, las sociedades cristianas, otorgaban a la mujer. La mujer no toma parte en el acto de la generación, sino que concibe, esto es, porta la simiente en su seno y dá a luz los hijos. En casi todas las tradiciones, la mujer

19 A. CEA GUTIÉRREZ, Religiosidad popular, imágenes vestideras (Zamora, 1992), pp. 132-137.

20 Son numerosas las representaciones similares en la escuela románica catalana. En un frontal procedente de Col, del Museo Diocesano de Vich, se simultanea la escena de la Natividad con la de la duda de José. No obstante, debe recordarse la que quizás sea más antigua representación visual en España de la escena de la Natividad, la ilustración del antifonario mozárabe de la Catedral de León (manuscrito realizado a principios del s. $\mathrm{x}$, con posibles prototipos del s. VII, ya que es una copia de otro fechado en el 672), presenta a María y a José, imberbe, sentados a ambos lados del pesebre donde yace Jesús, fajado. (J. CAMÓN AZNAR, Pintura medieval española (Madrid: Summa Artis, 1966), XXII, pp. 22-23). En el Museo de San Martino, de Nápoles, se conserva una escultura de María yacente en el lecho, obra datada en el siglo xIv. 
se identifica con la tierra, que recibe la semilla y crece esta en ella. Por tanto, el acontecimiento de la maternidad no tenía entonces el mismo valor que ahora, pues suponía simplemente el logro de un fruto ajeno, que tarde o temprano había que devolver a su legítimo dueño.

Y esa idea de la implantación de un ser completo, sin aportación ninguna de la mujer a su conformación, viene dada en las representaciones de la Anunciación en las que se ve entrar al seno de María un pequeño cuerpecillo infantil, representando a Jesús, idea acorde con el conocimiento de la época: María como recipiente, vaso sagrado de una entidad completa, en este caso, el propio Dios. El parto es incompatible con la idea de virginidad anatómica. Por tanto, los Padres de la Iglesia deben tratar tempranamente tan espinoso asunto. Sólo elevando biológicamente a María sobre todas las demás mujeres puede plantearse una contemplación tranquilizadora ante tan turbadores eventos, que suelen ocultarse a la vista de los varones. Quizás esta sea una de las explicaciones de por qué el culto, rayano en la idolatría, que en algunas épocas se llegó a profesar a María, no trajo consigo una elevación del papel social de la mujer, junto con la dignificación de la maternidad y el parto.

Pretende ser una explicación de la propia idea del Nacimiento de Jesús como representación limpia, visible por todos. Por ello quizás, la representación móvil que definimos como Nacimiento o belén, surge, desde sus comienzos conocidos, como adoración a Jesús más que como figuración de un parto, basándose iconográficamente en las visiones de Santa Brígida, quien refirió cómo, llegado el momento, José salió del establo para buscar una partera y, mientras, María, orante, se dió cuenta de la presencia de su hijo recién nacido que reposaba, desnudo, sobre los pliegues de su manto. Según ello, aunque se figure la escena nada más nacer el Infante, la Madre no se debe mostrar postrada por el esfuerzo biológico realizado. El parto, entonces, ha tenido lugar en circuntancias excepcionales. Si María no aparece con trazas de dolor no es por ahorrarle sufrimiento -que despues le acompañará toda su vida - sino porque no le sucede nada de lo que causa dolores atroces al resto de las mujeres. Al hablar de las parteras veremos cómo la iconografía pictórica y escultórica va desechando todo lo relacionado con el alumbramiento común, como el lavado del infante. Es tan imperiosa la necesidad de presentar a Maria por encima de la condición femenina, sometida a la naturaleza, que, en la representación, se llega a pasar por encima de otro importante tabú: el cabello femenino. Toda mujer casada debía ocultarlo como muestra de honestidad. Pero en este caso se elige entre ambas significaciones y, puesto que María, aunque casada, es doncella en sentido literal, en la Baja Edad Media vuelve a aparecer su figura dejando velo y tocas para lucir largos cabellos, privilegio de las solteras. Aún se puede ver de tal forma en el belén del Hospital Municipal de Palma y en las figuras procedentes del 
retablo de Nuestra Señora de Belén de Carrión de los Condes ${ }^{21}$, por poner dos de los ejemplos más antiguos conocidos en España. A lo largo del siglo XVII y parte del s. XVIII, la imagen de María velada se mantendrá en los belenes de figuras móviles de menor tamaño, mientras que las mayores, especialmente las vestideras, optan por presentar a María con el manto.

José

José, el casto esposo de María, ocupa un lugar delicado en la historia de la Natividad. Sin ser el auténtico padre de Jesús, lo es ante los hombres. Se han propuesto diversas solucio-

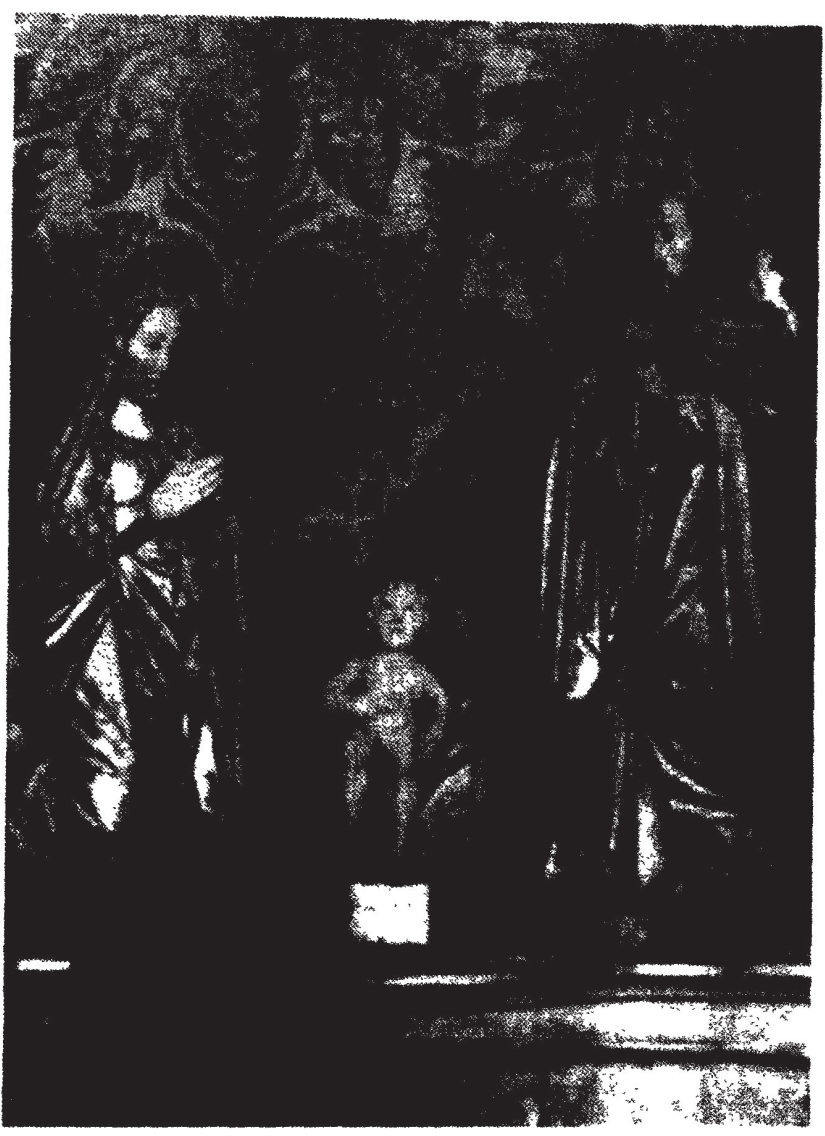

LÁM. IX.-Figuras de la Natividad. Siglo XV. Santuario de $\mathrm{N}^{2} \mathrm{~S}^{2}$ de Belén. Carrión de los Condes (Palencia). nes iconográficas para destacar los diferentes aspectos de esta singular figura. Es curioso cómo, a lo largo de la Edad Media, José es caracterizado con ropajes de judío. Son frecuentes las imágenes del patriarca con el sombrero puntiagudo de uso obligatorio para los varones judíos en varios países de Europa. En España, donde tal variante de tocado no existe, aparece sin embargo en algunas representaciones, prueba de la inspiración extranjera de estas. La iconografía local lo pinta con bonete hendido o picudo (prendas asimismo portadas por judíos) o, más adelante, portador de gramalla y capirote. Posteriormente, tal vestimenta se hace incompatible, debido al antisemitismo de la sociedad europea del siglo XV. A partir del Renacimiento y tras la Expulsión de 1492, sus vestimentas se vuelven progresivamente incoherentes, puesto que el influjo flamenco introduce la interpretación de una moda extraña y, como ya hemos hablado de ello en otras ocasiones, un acento malévolo, casi caricaturesco, de cualquier personaje novotestamentario

21 Publicado, en la obra ya citada de Ángel SANCHO CAMPO, lám. 58. Aunque se presenta como parte de un retablo, la disposición móvil de las figuras, exentas y de un tamaño de 60-70 cms. de alto, resultan muy adecuadas para la formación de un Nacimiento móvil. 
caracterizado como hebraico. La razón de esta insistencia en lo judaico quizás se deba a la justificación de la genealogía de Jesús a través de José, difícil de interpretar, pero plausible como símbolo del tipo de paternidad que el pueblo de Israel otorga al Dios encarnado. Así, como padre putativo, representaría al pueblo de Israel en cuyo seno nace y vive Jesús, y aquella parte de este pueblo que es fiel a su doctrina. Por tanto, José sería un «justom, al estilo veterotestamentario, pero no un "santo" como los del Nuevo Testamento. Ese rango secundario en la jerarquía parece advertirse en algunas pinturas, especialmente de la escuela catalana, donde aparece José nimbado con aureola estrellada, de lados cóncavos, tal como los reyes Magos, la Magdalena o José de Arimatea en los respectivos pasajes. Sin embargo, María y el Niño se adornan con nimbos circulares, al igual que las representaciones divinas y de los santos ${ }^{22}$. Otro atributo es el de la vara. Recordemos cómo, en la tradición apócrifa, al tener lugar los Desposorios, la vara de José floreció, refiriéndose, dentro de la hebraica, a su condición de Justo. Para acentuar el detalle, los pretendientes de María aparecen en diversas pinturas, alguna tan conocida como la de Miguel Angel, en la Pinacoteca Brera, partiendo sus varas. La vara florida es, asimismo, atributo de Aarón, protagonista secundario en el éxodo de Israel y su liberación de la esclavitud. Un símbolo, en definitiva, del Antiguo Pacto, sustituido por el Nuevo. Ciertamente, la vara florida resulta indispensable en los Nacimientos de figuras móviles, mientras que en las representaciones pictóricas más antiguas no se aprecia nada especial en el cayado de San José, salvo su símbolo como patriarca.

Otra forma de alejar visualmente a María de José es acentuar la decadencia física de este, al lado de la, cada vez más, pronunciada juventud de María. Tras la línea seguida durante la Edad Media, la iconografía flamenca llega a presentar a José como un cadáver salido del sepulcro, descarnado y con ralos mechones, de aspecto desagradable, encogido en un rincón del portal, durmiente o, peor aún, ávido custodio de los presentes de los Magos ${ }^{23}$. La

22 Son ejemplos la famosa Epifanía del Retablo del Condestable de Portugal, pintada por Jaime Huguet, la zarza ardiente de la Catedral de Tortosa, realizada por el mismo autor, donde se contrapone el nimbo circular de Dios Padre con el estrellado de Moisés. Esta tendencia, sin embargo, no es general, ya que en un anónimo aragonés del s. xv, perteneciente a la iglesia parroquial de Tamarite de Litera (Huesca), donde se representa la entrada de la Virgen Niña al servicio del Templo, es San Joaquín quien luce nimbo estrellado, mientras que las escenas de la Natividad y la Epifanía, pintadas por los Jiménez para la misma parroquia, presentan a San José con el nimbo circular. Otras relaciones de mayor/menor rango espiritual, determinadas por el tipo de nimbo se aprecian en representaciones de S. Joaquín-Sta. Ana. o de Nicodemo y José de Arimatea, contrastando con las tres Marías.

23 La influencia de esta visión es innegable en la llamada escuela hispano-flamenca, que sigue muy de cerca los modelos de Flandes. A tal visión no escapan artistas de la talla 
literatura popular acentúa la torpeza de José, convirtiéndole en un personaje achacoso e inútil, aunque de extrema bondad. Este hombre, al que ninguna mujer se uniría por gusto, es sin embargo el compañero de la bellísima y singular María, y guardián del Hijo de ésta. Sólo tras el Concilio de Trento se reivindica la figura de José, que pasa, como antaño, a ser un hombre joven, de agradable aspecto, modesto y de buen talante. La piedad española no es ajena a tal cambio y la propia Teresa de Jesús propicia tiemos modelos de José con Jesús en brazos. En los nacimientos españoles, un José ennoblecido, de caballerosas facciones, no viejo, será, desde el siglo xuI, el habitual compañero de María. En cuanto a su actitud como durmiente o retirado de la escena, se debe, probablemente, al pudor, combinado con la necesidad, al introducir un personaje masculino en una escena, como la del parto, exclusiva del mundo de las mujeres. Ferreira recuerda que en la sociedad medieval, predominantemente masculina, era el bautizo el primer acto al que el padre asistía, testimoniando socialmente el reconocimiento de la paternidad ${ }^{24}$.

\section{Personajes secundarios}

\section{Las parteras}

La mujer precisa una asistencia mínima, principalmente ofrecida por mujeres, las comadronas o las parteras, quienes, además de ayudar a la madre, se hacen cargo de los primeros momentos del recién nacido. Como ya hemos señalado, en las sociedades masculinas, los hombres suelen estar ausentes del momento del parto, por lo que queda convertido en asunto de mujeres. Así se ve claramente en la Natividad del frontal del Monasterio de Iguácel, en Huesca, donde José, meditabundo, da la espalda a su esposa encamada y atendida por las dos parteras. En la mayor parte de las representaciones altomedievales de la Natividad, se está describiendo un parto biológico, con la madre acostada tras el esfuerzo y, a veces, las parteras lavando al recién nacido. Salvo la presencia de los animales, en poco o nada se diferencia de la escena de la Natividad de la Virgen o la de San Juan Bautista, dos escenas habitualmente representadas. Sin embargo, Rops recuerda la leyenda de la partera incrédula, a quien, al intentar comprobar la

\footnotetext{
de un Fernando Gallego, (Epifanía, Museo de Arte de Toledo, Ohío), Alonso de Sedano, quien lo presenta calvo y con uno de los dones de los Reyes en la mano (Epifanía, Catedral de Burgos),o el Maestro de San Nicolás, que lo muestra acurrucado y dormido sobre el cayado (Epifanía, Museo Diocesano, Burgos). Pero José, envejecido y apartado, aparece también en manuscritos bizantinos y armenios.
}

24 FerReira DE Almeida, op. cit., p. 9. 


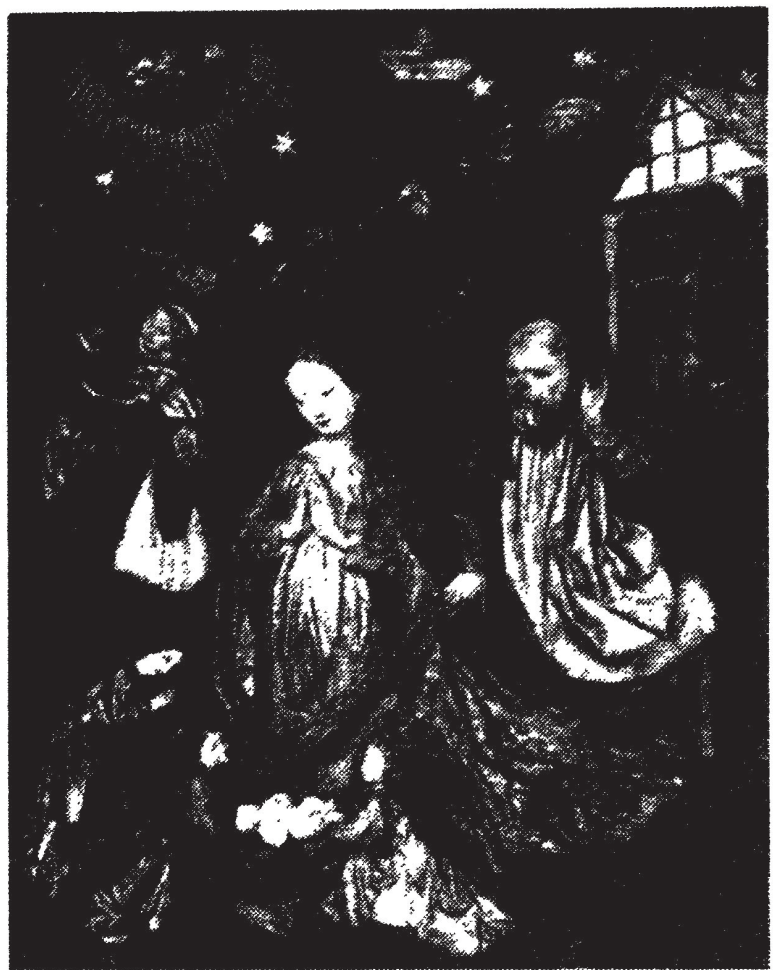

LÁM. X.-Altorrelieve con la Natividad, llegada de San José y las parteras. Siglo XV, escuela alemana (Liebieghans, Museum Alter, Plastik, Frankfurt).

virginidad de María tras el parto, se le seca la mano, asunto que simboliza una creencia piadosa de fuerte arraigo $^{25}$. Hasta tal punto en la Edad Media es asumido el parto de Jesús como un hecho biológico normal, que una de las escenas más repetidas es la del baño del infante por las mujeres. Ferreira explica el vigor de estas representaciones, contrarias al texto del propio Evangelio, a la posterior doctrina de San Jerónimo, y a la de San Bernardo de Claraval, como imposición de un patrón social que servía para indicar, primero, que el recién nacido estaba vivo, y mostrar su sexo. Sin embargo, en el púlpito de Pistoia, obra de Nicola Pisano, hacia 1268, vemos al niño de pie sobre una pila, al igual que en los iconos orientales. Si consideramos que es una obra realizada para una catedral, parece extraño que difiera de la corriente oficial que comienza a considerar el parto de María como virginal y sin dolor, surgiendo el Infante totalmente limpio. La ausencia de los fenómenos naturales del parto hacen inútil la presencia de las parteras, $o$, al menos sus tareas. Pero, si se sigue representando el lavatorio del recién nacido, quizás se deba a su similitud con el bautismo, lo que explicaría la presencia del Niño en pie. Cabría una interpretáción mística si se considerara que las parteras son en realidad las antiguas sibilas que han asistido espiritualmente. con sus vaticinios, al parto del Salvador, y que estos se cumplen, precisamente, al nacer físicamente éste. La escena tendría entonces sentido como prefiguración del Bautismo, recibiendo a la Gentilidad (sibilas Cumana, Tiburtina), en contraposición al mundo judío. De hecho, la figura del Jesus infante sobre la fuente, coincide con el estereotipo de los Niños Jesüs espanoles de devoción particular, aparentando una edad entre cuatro y siete años, se muestra erguido y desnudo, frontalmente colocado, con los brazos ligeramente separados, y las manos normalmente en actitud de bendecir. En el folklore tradicional español $y$, especialmente en las representaciones teatrales

25 Ver D. Rops, "Traditions et légendes autour de la crêche", ECCLESLA, 10 (1950), pp. 27-32. 
del ciclo, se conserva viva la presencia de dos mujeres, designadas con nombres propios, que, como el de Salomé, recuerdan a los personajes femeninos propuestos por el Protoevangelio de Santiago. La tradición dramática viene de antiguo, pues en la antífona "Hodie Cantandus" de Tutilón de San Galo, tenida como la más antigua de las dramatizaciones navideñas, dos actores, que representan a las parteras, saludan a los primeros pastores que se aproximan al establo.

Sin embargo, en los Nacimientos de figuras móviles no conocemos escenas del lavatorio de Jesús, y las parteras pueden haber sido reemplazadas por pastoras $\mathrm{u}$ otras figuras femeninas orantes.

\section{Los pastores}

Citados en el relato de San Lucas, los pastores son invitados a irrumpir en la escena sacra, en la intimidad familiar que rodea al recién nacido, donde se juntan lo celeste y terrestre, según el anuncio del ángel. En efecto, los pastores y sus ovejas aparecen en las representaciones medievales, donde los rústicos, tres por lo general -dos en las representaciones bizantinas-, reciben la embajada o bien aparecen en la mismísima escena del alumbramiento, ataviados a la usanza popular y en actitud curiosa y viva. En toda Europa se tiende a caracterizar claramente estas figuras como de campesinos locales, incluyendo sus atuendos específicos, tal y como, por ejemplo, se puede constatar en el tríptico de la Natividad del llamado Maestro de Avila, que se conserva en el Museo Lázaro Galdeano. Los tres pastores que aparecen incluyen un gaitero, de presencia habitual en los primitivos Nacimientos. Según una antigua tradición, en Ledesma se conservan los restos de estos tres primeros pastores, cuyos nombres tradicionales Isacio, Jacobo y Josepe, aparecen en el milagro de Villarta de los Montes, transcrito por Isabel Ga11 ardo ${ }^{26}$. La fijación en tres del número de pastores parece corresponderse con el número tradicional de magos. En principio y ya que la aparición del rey negro se sitúa en torno al $s$. XIV, representarían las tres edades de la vida consciente: juventud, madurez y senectud, cada grupo en su clase social correspondiente. Primero son los humildes quienes reconocen al Mesías, y, posteriormente llegarán los poderosos a rendirle tributo. En la estructura social de la Edad Media, el reconocimiento de un monarca pasa, primeramente, por el tributo de vasallaje de los súbditos y, posteriormente, por el de los señores.

En el teatro del ciclo de Navidad, los pastores son parte sustancial, pues representan los ojos a través de los cuales los espectadores asisten al evento.

26 Isabel Gallardo DE ÁlvareZ, "El Milagro de Villarta de los Montes (o "Hacer los Reyes")m, R.D.T.P., XIII (1957), pp. 507-525. 
El pastor músico, en contraposición al ángel músico, suele aparecer, en los belenes italianos, al lado de las ovejas que, aún a través del tiempo, siguen siendo uno de los elementos característicos de la representación belenística, sin que falten en ninguno de los montajes tradicionales.

Otros personajes de las representaciones navideñas se incorporan en efigie al Nacimiento: las dos gitanas, por ejemplo, que asimismo aparecen en la representación de Villarta de los Montes, cuyo papel consiste en piropear, una a la virgen, mientras otra pone en ridículo a José llamándole viejo y barba de chivo, le roba los regalos de los Magos y le compara con la belleza de su esposa, a quien la primera pronostica un amargo futuro. $\mathrm{O}$ los ángeles, representados por donceles

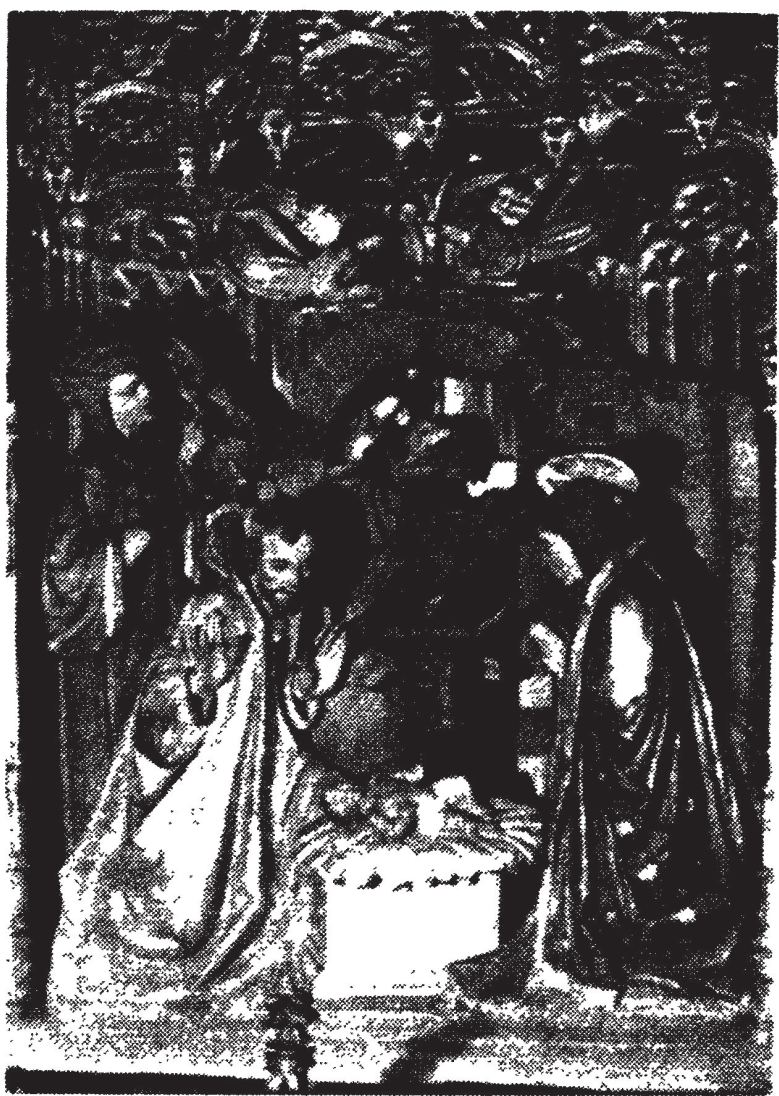

LÁM. XI-Grupo de la Natividad con los tres pastores. Retablo mayor de la Catedral de Oviedo. Siglo Xv. o mozas sobre caballos blancos con las pezuñas pintadas de purpurina, el de los Magos portando estrella plateada, imagen conservada en los belenes barrocos americanos, como el del convento de Santa Clara de Quito ${ }^{27}$.

En España son frecuentes los casos de individualización, mediante nombres pastoriles, de diversas figuras de Belén, casi siempre en relación con personajes de representaciones. Así recoge Llompart los nombres de "Tonet, Toneta, Blai y Blaia" utilizados en el de S. Jerónimo de Palma. Y en los pastorells o autos de Navidad se encuentran nombres de raigambre hebraica: Rebeca y Susana (s. XIX), Jafet, Sofonies, Dalia, Zabulón, David... Cea Gutiérrez relaciona nombres castellano-leoneses como Blas y Menga con las Églogas de Juan del Encina, posiblemente contemporáneas de las figuras que los llevan ${ }^{28}$. Con el transcurso del tiempo, sobre todo a partir del gusto costumbrista dieciochesco, la figura del pastor destinatario del Anuncio se amplía a todos los oficios y representaciones de las clase humildes, que acuden con ofrendas de diversa índole, bailan, cantan y se agrupan en

\footnotetext{
27 Ver V.V.A.A., El belén, bistoria tradición y actualidad (Madrid, 1992), p. 86.

28 RDTP, XXVI, p. 57. Ver Antonio CEA GUTtERREZ, op. cit, pp. 134-137.
} 
diversas actitudes, ofreciendo infinitas variaciones y posibilidades de construcción de los belenes móviles. En los belenes antiguos, la tradición se mantiene y los pastores son protagonistas exclusivos, si se exceptúa algún músico.

\section{Los Reyes Magos}

El misterio de la procedencia de los magos, su número y su estatus social (reyes, sacerdotes, astrólogos) han atraído sobremanera a los comentaristas e iconógrafos, produciendo una abundante literatura.

Para el tema que nos interesa, los Magos, cuando viene a florecer la tradición belenística, ya tienen su número fijado desde casi un milenio atrás, y de ser los persas que mencionaba Prudencio, pasan a convertirse en representantes de las tres razas descendientes de Noé, o las tres razas más importantes de la gentilidad, como quiere el Evangelio Armenio de la Infancia.

En cuanto a la llamativa presencia del rey negro, indispensable en nuestros belenes, es posible que tenga su origen en la visión de Santa Isabel de Schnauge, quien declara taxativamente que el Rey Baltasar era negro. A pesar de ello, la iconografía incorpora muy lentamente esa novedad, y los modelos más tempranos se sitúan doscientos años después, en las obras de la escuela renana.

Del concepto primitivo persa del mago como sabio sacerdote, pasamos al concepto de monarcas, propiciado por la sociedad medieval, para quien tenían más importancia la nobleza militar que los intelectuales e incluso los clérigos. Sea por la razón que sea, los Magos aparecen con insignias reales (coronas) y, aunque se encuentran desde el s. XII representaciones de camellos en su cortejo, Masseron ${ }^{29}$ recuerda que sólo montan en caballo, realzando así el concepto medieval del caballero cristiano, y sus figuras suelen presentarse lujosamente ataviadas, lo más posible, con dos modalidades: a caballo, esto es, en viaje, y en el acto de adoración que constituye la escena de la Epifanía.

En los antiguos belenes europeos suelen estar representados, como ya se ha dicho arriba, los pastores, situados por lo general en una montana sobre la gruta. Posteriormente aparecen en compañía de los personajes centrales, coincidiendo con la transformación de la gruta en establo derruído, paso de un escenario cerrado, vedado, a otro abierto, que permite el acceso a indiscretos. En el primer caso, los magos cruzan a caballo, normalmente por el fondo, el escenario montuoso. En el segundo, se suman a los pastores, llegando a arrebatarles el protagonismo. Como ya se verá más adelante, la tradición de mover las figuras del belén, obligará a poseer dos juegos de

29 A. MASSERON, :Les Rois Mages", ECCLESIA, 10 (1950), pp. 73-77. 
Magos, uno para sus jornadas y otro en adoración, extremo que Llompart constata en algunos conventos baleares.

Uno de los conjuntos más antiguos de figuras móviles que se conservan en España con los Magos en adoración, es el de Melgar de Fernamental, y son figuras de buen tamaño, parecidas a las de los belenes de Apulia ${ }^{30}$.

Pese a lo controvertido de la ubicación temporal de la Epifanía, y aún consciente de la distancia temporal, la tradición belenista se muestra unánime al hacer coincidir esta - al estilo de los retablos medievales, donde todas las escenas transcurren al mismo tiempo- con la Adoración de los pastores y la de los ángeles, completando el sentido hierofánico que antes atribuíamos al belén: la presencia de la Trinidad desvelada, los coros ángelicos, los hombres llanos y nobles de la tierra, el ignorante y el sabio, e incluso las criaturas todas adorando al Dios Encarnado. Ese sería - creemos- el sentido completo de la representación belenística, triunfal y profundamente distinto al propuesto por San Francisco de Asís, que hoy se considera como arranque de dicha tradición. Así se aprecia en la pintura del s. XV, y en algunas obras escultóricas, en buena parte procedentes de los Países Bajos, entre ellas el tríptico de Santibánez de Zarzaguda, en cuya escena central vemos reunidas todas las características del Nacimiento móvil ${ }^{31}$.

\section{Otros personajes}

Numerosos personajes se incorporan lentamente a las escenas de la Natividad, y ello se debe quizás a la influencia de las obras teatrales del ciclo navideño, que, además de ambientarse en el Anuncio y Adoración de los Pastores, relatan la llegada de los Magos y la Epifanía, las conversaciones de estos con el Rey Herodes, la discusión del monarca con su corte y la matanza de los Inocentes.

Devociones aún en vigor, como las jomaditas ${ }^{32}$, retrotraen la narración a episodios previos al nacimiento de Jesús, como la petición de posada. Se incorporan además la Anunciación, el aviso celestial a José, los Desposorios y otras escenas, hasta constituir un retablo completo de la infancia de Jesús. Estas es-

30) Ver el comentario de Alberto C. IBÁNEz PÉREz en el catálogo de la exposición Las edades del bombre (Salamanca, 1988), p. 238. La figura que aparece de pie, sin corona, es San José, con el gesto habitual de sujetar uno de los recipientes con los dones de los Magos.

31 Ver el comentario de Alberto C. IBÁṄez PÉREZ, op. cit., pp. 81-82, y de L. ARBETETA MrRA, "Belenes del Museo Nacional de Artes Decorativas" (Zamora, 1991), p. 6

32 La descripción de la tradición de las Jornaditas, tal y como se celebran en Andalucía, ante figuras de la Virgen y San José con atuendos de caminantes, con o sin borriquillo, viene recogida por José Maria GOMEZ SÁNCHEZ, El Belén en Sevilla (Sevilla, 1981), p. 6. 
cenas necesitan sus correpondientes protagonistas, indispensables en los grandes belenes populares españoles: El Rey Herodes con sus soldados, los pajes del cortejo de los Magos, el posadero que niega la posada a los santos esposos, los Inocentes y sus madres, luchando contra sus verdugos, danzantes, pescadores, lavanderas... personajes de ambientación y oficios, cada vez más anacrónicos a medida que el relato se complica y el tiempo avanza. Algunos personajes, escenas y elementos, presentes en los belenes tradicionales, tienden a desaparecer, como el cazador, el ermitaño, Adán y Eva, las sibilas y profetas, el dosel de Herodes, desde donde contempla la Degollación, la abundante fauna salvaje y exótica (serpientes, lagartos, leones, perdices, monos, flamencos, cigüeñas) la escena de la Visitación, la Duda de José, la Circuncisión...

\section{Elementos escenográficos}

\section{La cuna}

Es fundamental la representación del pesebre, simbolo del nacimiento de Jesús en un ambiente de pobreza extrema. Además de las razones ya especificadas al tratar sobre los animales, el pesebre, como contenedor físico, está considerado como el inicio de la escenificación belenística, vinculado a la tradición franciscana, aunque algunos historiadores se oponen a tal tradición, especialmente Grisar. Como ya vimos, di Celano narra el milagro que tiene lugar durante la celebración de la misa de Greccio, y que consiste en la visión de un caballero presente, quien vé al Niño Jesús exangüe entre los brazos del Santo, y cómo, poco a poco, vuelve a la vida. Este episodio, relatado de diferentes maneras, suele considerarse inicio de la costumbre de instalar el belén, pero, casi con seguridad, tal costumbre existiría anteriormente. El milagro, al igual que el de los ángeles arantes y San Isidro, ha sido tradicionalmente mal interpretado. San Francisco no instituye el belén en la noche de Greccio, sino que revive con su amor al Niño Jesús que duerme en nuestros corazones. La devoción clarisa por el Jesús durmiente, así como la mayoría de las tradiciones monjiles espanolas recuerdan el "despertar" milagroso de Jesús en los corazones, "nacimiento" particular que ha de operarse en el interior de cada cual, y que se simboliza con una larga tradición de estatuas de Jesús durmiente sobre las rocas del campo o bien sobre artísticas cunas o camas. Las manifestaciones del culto navideño más antiguas de las que se tiene noticia son, precisamente, las tettoie italianas, las cunas de Navidad medievales, especialmente las del área germánica ${ }^{33}$ y el llamado

33. Especialmente interesantes son los datos reunidos por Anna BUONICONTINI AsCHEtrino, en su aún inédita ponencia del Congreso Internacional Belenista, tiulada all 
repós de Jesús, donde la cuna adquiere valor protagonista. El culto como reliquia a la verdadera cuna de Jesús, traída de Tierra Santa, fue eje de devociones muy anteriores a la franciscana, especialmente en Roma, a partir de la construcción de un simulacro de la cueva del pesebre, durante el papado de Sixto III. Este y otros datos, por lo conocidos, se pueden comprobar en cualquier historia de las representaciones de la Natividad ${ }^{34}$, a las que remitimos ${ }^{35}$.

\section{La estrella}

La estrella, es posiblemente con el pesebre, uno de los símbolos específicos de la Natividad de Cristo. El texto del Pseudo Mateo relata cómo una estrella inmensa resplandecía sobre la gruta, fenómeno al parecer independiente de la que guiaba a los Magos. Como símbolo principal ha recibido también una gran atención por parte de los iconógrafos. Para conmemorar la Natividad de Cristo, el cristianismo seleccionó del calendario pagano las fiestas relacionadas con la luz y el resurgimiento del sol. El 25 de diciembre, commemoración del nacimiento de Mitra, era fiesta dedicada al sol (Natalis Solis Invicti) y el 6 de enero al solsticio de invierno. La primera aparece ya en la relación del cronógrafo o calendario de Filócalo, en el año 354, y la segunda, dedicada a la Epifanía o la manifestación de Dios a los pueblos gentiles, se comienza a celebrar años después. En ambas una estrella sirve como indicador de los acontecimientos. Iconográficamente, existe una tendencia a fijar la estrella de ocho puntas rectas como modelo, basándose en antiguas interpretaciones solares. Idéntica a la que aparece en ciertas monedas bajoimperiales se encuentra en el célebre mosaico de Santa María la Mayor de Roma, donde, además, un largo haz de luz cae verticalmente desde la estrella a la cabeza del recién nacido.

presepe napoletano nel suo sviluppo dalle origini al xIX secolo. En este trabajo, del que gentilmente nos proporcionó un ejemplar mecanografiado, cita a Borelli y Stefanucci, de quien recuerda sus teorías acerca de los tropos litúrgicos como origen de las representaciones dramatizadas del ciclo de Navidad, y recuerda la tradición de las estructuras de troncos de abeto, "tettoie, a modo de pesebre que, desde el siglo Iv, ambientaban algunas iglesias romanas durante la Misa de Medianoche o de la Aurora, antecedente de la Misa del Gallo actual.

34 Véase, además de las obras ya citadas, la reciente de Gennaro Borrelli, Scenografia e scene del presepe napoletano (Nápoles, 1992).

35 Pueden consultarse, al respecto, las obras de O. CuLuman, El origen de la Navidad (Barcelona, 1956); la clásica de R. BERuNER, Die Weihnachtskrippe (Munich, 1955), entre muchas otras. La primera, más específica, analiza, asimismo, las influencias paganas, especialmente las derivadas del culto de Mitra. 
Quizás, en el mundo del belén, la estrella sobre el lugar del nacimiento sea, en realidad una representación de la luz de la presencia divina, manifestada en las dos Personas de la Trinidad, pues se tiende a suprimir la estrella cuando estas se escenifican, aunque se conserva el haz de luz, como el que conforma la Gloria mallorquina ya descrita. En cuanto a la estrella de los Magos, se suele presentar como un cometa, o algún tipo de estrella errática, de brazos flamígeros.

Una miniatura del códice francés Les Très Riches Heures du Duc de Berry, conservado en el Museo Condé, de Chantilly, presenta a los Magos que, según la tradición de Beda el Venerable, proceden de los tres continentes conocidos, guiados por distintos caminos por la misma estrella, y que se juntan ante un hito de caminos.

En todo caso, la estrella es símbolo capital y antiquísimo para la escenificación belenista, y su presencia es obligatoria en las representaciones navideñas.

\section{La cueva}

El lugar donde tuvo lugar el nacimiento real de Jesucristo ha sido objeto de todo tipo de opiniones. La presencia de animales sugiere un establo, y la tradición sugerida por los apócrifos, especialmente por el protoevangelio de Santiago, nos translada a una cueva. Los peregrinos que visitaban Belén encontraban una especie de habitación subterránea, prolongada, con una bóveda de medio cañón por techo. En un intento de simular este espacio se relizaron los grandes belenes de tipo italiano, de los que ya hemos hablado, y, entre ellos, el ya descrito de Palma de Mallorca. El fenómeno, como sugiere con acierto Amades, es similar al furor que en su época tuvo el reproducir naturalísticamente la gruta de Lourdes en capillas y oratorios. En la Edad Media, sea por la santidad del acontecimiento, sea por la ubicación subterránea de este, se tiende a reproducir la Natividad en un espacio cerrado, delimitado a veces por cortinas ${ }^{36}$, que nos hablan de intimidad y sacralidad. Posteriormente, al introducir a los pastores, la escena se abre para mostrar el campo, donde tiene lugar el Anuncio, y se sustituye la gruta por una choza o establo ruinoso, donde apenas pueden cobijarse los protagonistas. Creemos que, precisamente desde que se generaliza la costumbre de poner Nacimientos, la Natividad pasa a ser una escena pública, abundando en doble sentido de Kenosis y Teofanía que ya comentábamos. Posteriormente,otras soluciones más elaboradas pasan a ocupar el lugar de la gruta-alquería, como por ejemplo, los templos en ruinas de los belenes napolitanos, que, so pretexto de su simbolismo

\footnotetext{
36. Ver el apartado g) en FERREIRA, op. cit., p. 10.
} 
como la victoria del Cristianismo sobre el paganismo, introducen el tema arqueológico, tan de moda en los ámbitos ilustrados. En España, salvo en contados ejemplos, la escenificación tradicional suele estar constituida por una cueva de montaña, a la que se le añaden tejadillo y otros elementos constructivos. En el siglo XVII, quizás por la presumible influencia italiana, es frecuente encontrar belenes donde aparece un conjunto de elementos arquitectónicos de tipo urbano y rural (casa o posada, palacio o castillo de Herodes, conjunto de edificaciones, ermitas, puente, pozo, etc.) con los que se ambientan las diferentes escenas, unificando visualmente, a modo de retablo medieval, distintos episodios con los mismos protagonistas, acaecidos en momentos diferentes.

\section{ALGUNOS ELEMENTOS PROPIOS DE LOS NACIMIENTOS ESPAÑOLES}

A efectos de sistematización del presente artículo, se consideran como "españoles" los Nacimientos actuales e históricos que se hayan realizado en la zona geográfica que hoy constituye el Reino de España. Se exceptúan, por tanto, las áreas coloniales, pese a que, en su momento, formaron parte del mismo Reino, aunque se irán mencionando en el lugar correspondiente aquellos puntos de contacto necesarios para la comprensión cabal del fenómeno. Tampoco se mencionan aquí cualidades exclusivas de los Nacimientos espanooles, pues establecer tal categoría supondría un trabajo de comparación exhaustivo con todos los producidos por el resto de la cristiandad. Nos limitamos, pues, a señalar aquellos caracteres que, sin ser regla obligatoria, suelen aparecer con frecuencia en la construcción del Nacimiento español.

\section{a) La escena. Sus materiales $y$ disposición}

El escenario o maqueta donde se ubicarán las figuras móviles, puede dividirse en fijo, semimóvil y efímero, según se conserve, pasada la festividad, total o parcialmente, o bien no se conserve en absoluto, distinguiendo aquí si se preserva o no alguno de sus elementos. Aunque sería lo más práctico el poder realizar una clasificación tipológica ordenada por épocas, al no haber sido casi estudiada la documentación relativa al belén como uso y fenómeno, sólo nos es posible analizar, en estos momentos, los escasos belenes fijos que han sobrevivido al paso del tiempo, normalmente encerrados en mobiliario, armarios o escaparates, la mayoría de pequeño tamaño. Esta información, además, es fragmentaria, y corremos el riesgo de asentar premisas falsas, puesto que deben existir numerosos ejemplares en lugares de difícil acceso, especialmente conventos. No obstante, remitimos a un trabajo anterior en el 


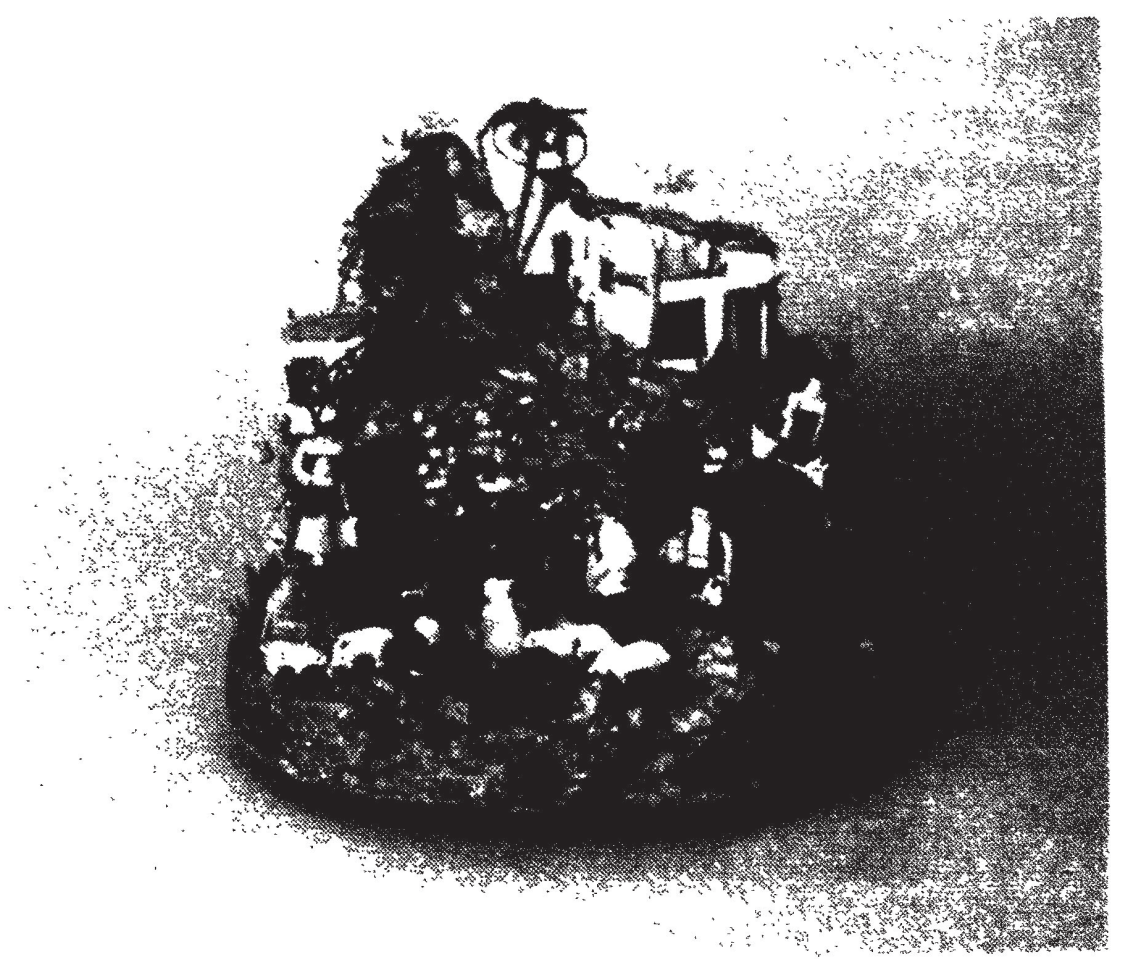

Lám. XII.-Belén conventual de los llamados sacro-montes, bajo fanal. El Puerto de Santa María, c. 1850. (Col. part.).

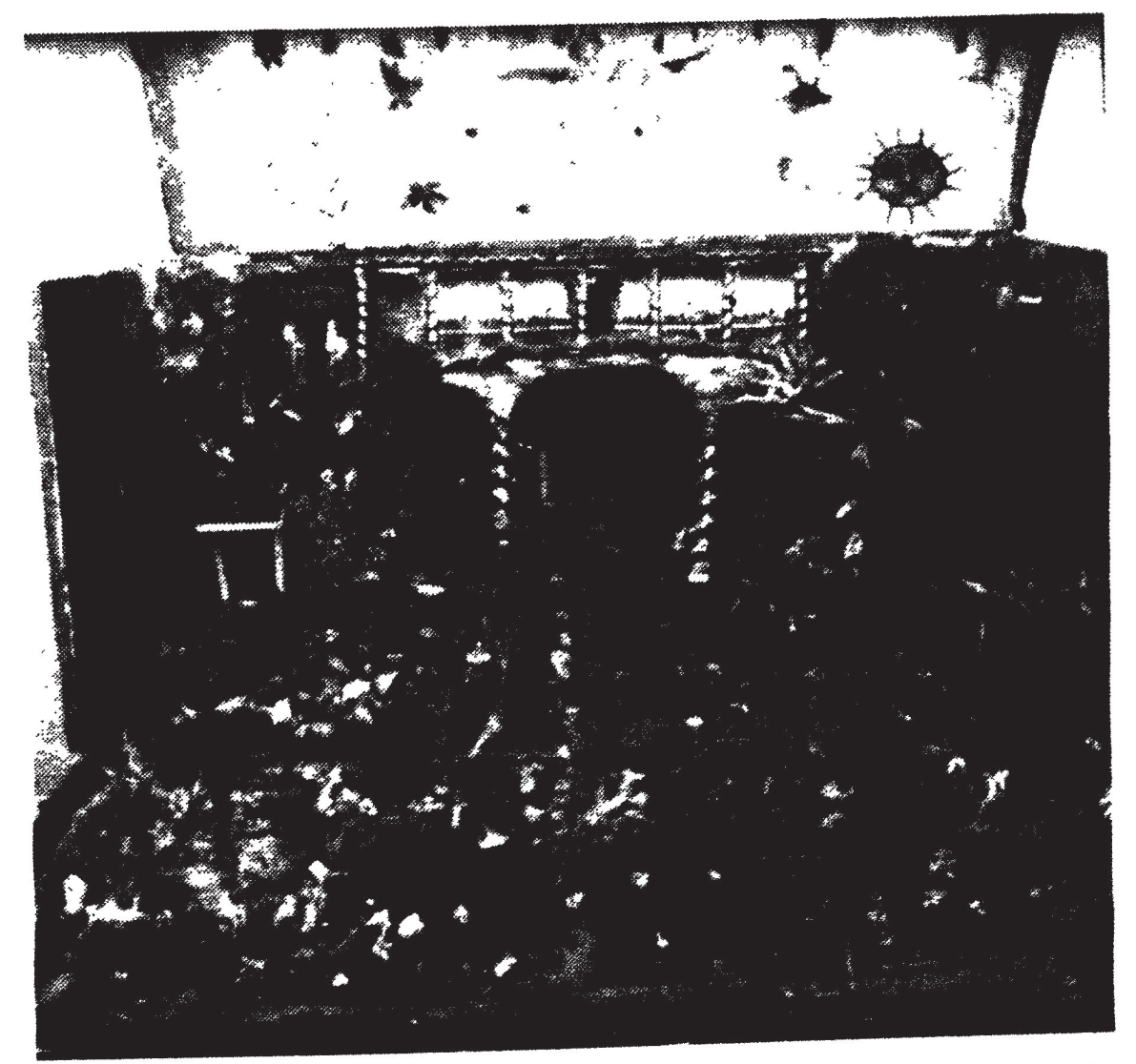

LÁM. XIII.-Belén peruano abridero del s. XVIII en un arcón. (Col. M. de la Quadra Salcedo). Fot. M. J. del Amo. 


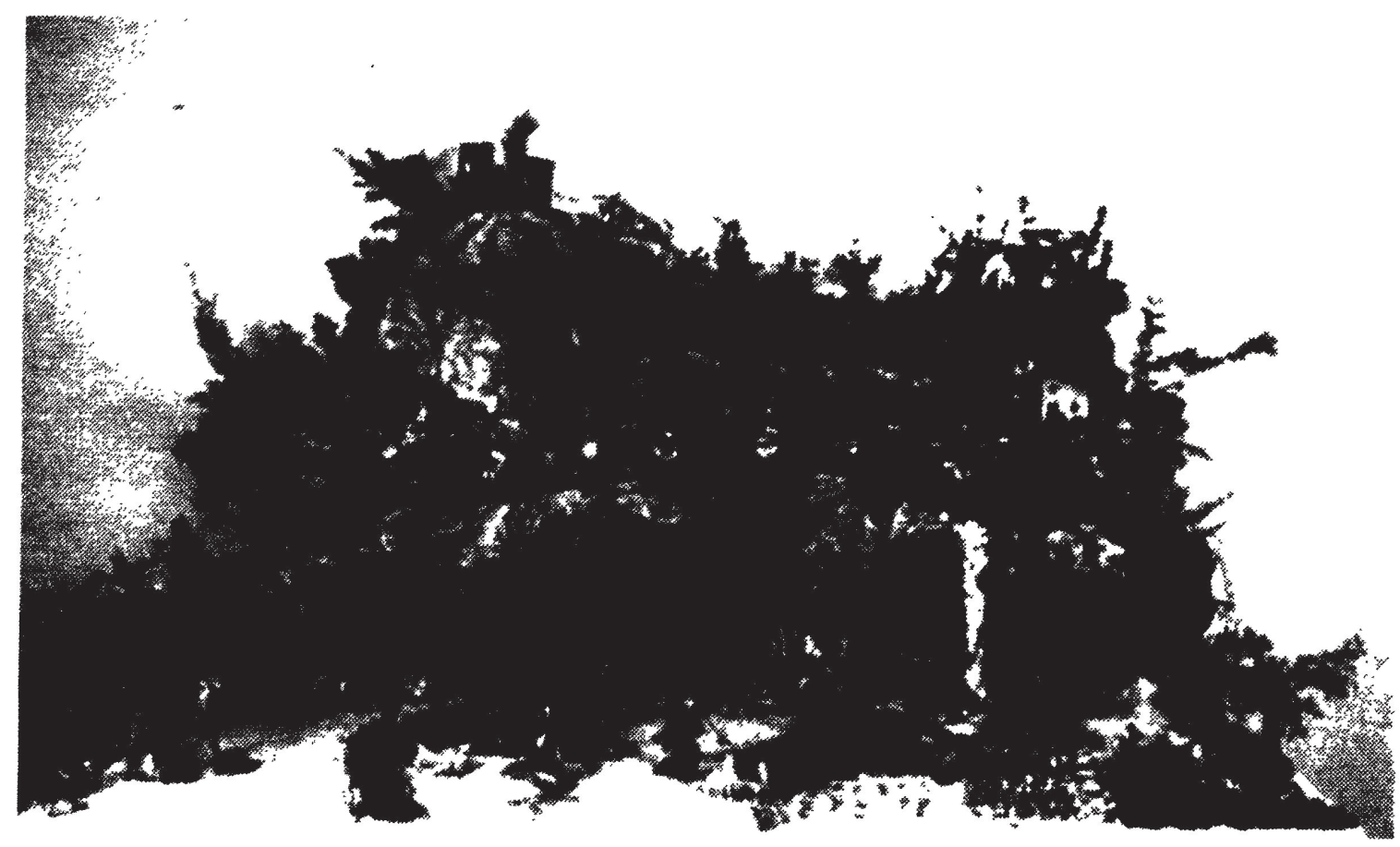

LÁM. XIV. Nacimiento de tipo tradicional, en papel jaspeado y figuras andaluzas. 1993 (Asociación de Belenistas). Fot. M. J. del Amo.

que presentamos una clasificación tipológica y cronológica provisional, en atención a los materiales que hoy nos son conocidos. Ello permite dividir el escenario en fijo y temporal, entendiendo por el primero aquel que no es desmontado totalmente pasada la época navideña, y que podría incluir las formas que hemos dado en llamar sacro-montes, armarios-retablo, mueblesretablo y teatrinos, según se representen en forma abierta, a modo de montaña, o se contengan en algún armario o mueble, pudiendo ser este mueble desplegable, como el interesante arcón datable en el siglo xuII y procedente de Perú, propiedad de D. Miguel de la Quadra Salcedo ${ }^{37}$. Los materiales constructivos más tradicionales son la tela, el papel o el cartón encolado. Estos forman el armazón de la maqueta donde se sitúa el belén. El corcho y la escayola son de introducción muy posterior a los elementos citados, y aún sigue siendo tradicional, de Cádiz a Cataluña, el montaje casero con papel de embalaje o cartón arrugado, jaspeado con pintura para simular roquedales, y lentisco o ramas de pino o abeto tras los simulados montes. Las embocaduras, en el belén tradicional, son inexistentes, aunque la gruta-portal suele estar representada por una cueva abovedada, desproporcionada y bien centrada. Algunos detalles vegetales, en los belenes antiguos, se realizaban con trapo e hilachas; el agua se imitaba con láminas de mica o, simplemente vidrio. $Y$, curiosamente, no suelen faltar numerosas conchas y caracolillos, costumbre tanto portuguesa (lapinhas) como española, que se puede verificar

3. Ver Letizia ARBetETA, Exposición Descubre el belén, op. cit., pp. 172-176. 
en montajes procedentes del Puerto de Santa María, Baleares, Madrid,etc. Esta presencia de conchas marinas tapizando a veces los accidentes del terreno, se encuentra asimismo en algunos belenes italianos, principalmente sicilianos. Parece asociada a las construcciones manieristas realizadas con elementos naturales, como las grutas del jardín de Villa D'Este, en Tívoli, proyectadas por Pirro Ligorio, los productos del "Stil rustique francés, o más concretamente, algunas producciones con elementos marinos, como la realizada con conchas y corales que se conserva en el Castillo de Ambras, en Innsbruck. Limallas, espejuelos y oropeles producían efectos iridiscentes al encender candilejas; llegando las fechas navideñas, se incorporaban a estos montajes musgo y plantas naturales. Se enriquecían con elementos diversos, alguños extraños, como plumas o joyas prestadas, que se prendían a las imágenes vestideras. El fondo, actualmente un papel liso o con paisajes diversos, solía antaño estar pintado, bien con un paisaje ficticio, bien con un rompimiento de gloria, donde se colocaría el Padre Eterno con su Corte angélica, generalmente en representaciones nocturnas, con presencia de estrellas. Aunque es muy diversa la tipología de los belenes españoles, resulta común a todos ellos la presentación de un paisaje abrupto, montañoso,con oquedades donde se desarrollan una serie de escenas que, en los Nacimientos más completos pueden abarcar desde la creación del Hombre y su caída hasta el bautismo de Jesús en el Jordán. (Debe recordarse que estos cuadros o escenificaciones se podian contemplar, desde muy antiguo, en las procesiones del Corpus y que el ciclo litúrgico anual se representaba, especialmente la Pasión, con figuras móviles).

\section{b) Temática representada: su encuadramiento}

A efectos de comprender el fenómeno belenístico, consideramos un error desvincularlo de estas representaciones cíclicas, pues debería plantearse de nuevo el papel que la estatuaria religiosa de pequeño y gran tamaño ha tenido y tiene en este tipo de representaciones. Si tomamos como ejemplo los retablos, estos son, además de expositores programáticos de imágenes, auténticos anaqueles donde se guardan una serie de figuras que, o bien varían su papel con el transcurso de las fiestas ${ }^{38}$, o bien son protagonistas de representaciones escenográficas que incluyen complicados desplazamien-

38 Es el caso de tantas imágenes de la Virgen, por ejemplo, la célebre del Sagrario, Patrona de Toledo que se presenta como Inmaculada (sin Niño), o como Madre (con el Niño). Otro caso es el de la Virgen vestidera de La Alberca (Salamanca), estudiada pormenorizadamente por A. CEA. Sobre las distintas funciones que desempeñan las imágenes, véase el ya citado catálogo del mismo autor Religiosidad popular. imágenes vestideras (Zamora, 1992). 
tos de las piezas, como en el Auto de Navidad de La Guardia (Álava), el Misterio de Elche, o las distintas figuras articuladas, tanto fijas como procesionales, entre ellas, los antiguos calvarios pirenaicos y el de Ahigal, en Cáceres, cuya dramatización por articulaciones motivó aún en 1753 la prohibición del obispo de Coria, según recoge $\mathrm{Cea}^{39}$. Cabe recordar aquí las procesiones infantiles andaluzas y las escenificaciones de la Pasión que hasta hoy se realizan, bajo la forma del moderno diorama, en el área mediterránea, especialmente Cataluña y Valencia. La Natividad y la Pasión parecen haber sido, pues, los dos polos de estas visualizaciónes devotas, y son, desde luego, los temas que más frecuentemente encontramos en escaparates y pequeños oratorios. El elemento paisajístico suele estar presente en ambas, aunque más esquemáticamente en la segunda, dada la tendencia a prescindir del fondo pintado con la ciudad de Jerusalén. Es frecuente, también, encontrar asociadas ambas representaciones - Nacimiento y Pasión de Cristo- en los retablos y construcciones devocionales fijas.

\section{c) Uso de las figuras. La escala}

En cuanto al cambio de uso de las figuras y su movilidad, a partir de la generalización de la moda de vestir las figuras (hacia el 1600), las posturas de estas se hacen más flexibles y, en lo que a los Nacimientos se refiere, encontramos ejemplos de cómo la figura de María en la Anunciación sirve para la escena de la Natividad, o cómo María y José, con un simple cambio de atuendo (el sombrero de viaje o de peregrino) se adaptan a las escenas de los Desposorios, Búsqueda de Posada, Natividad, Circuncisión, Huida a Egipto...; lo mismo cabe decir de la cabalgadura, el Sumo Sacerdote, los ángeles, etc. Creemos que un rasgo fundamental del belén popular español, a diferencia de modelos escenográficos pictoricistas, como el napolitano, es la motilidad. Aún en nuestra infancia hemos podido comprobar cómo los Reyes Magos avanzaban día a día por el camino que conducía hacia el Castillo de Herodes y cómo tomaban el que conducía al Portal. Esto se complementaba con el avance de José y María por entre caminos y casas, para llegar al Portal, finalizando con la aparición del Niño Jesús sobre su cuna la noche de Navidad, todo ello coexistiendo sin problemas con otras escenas que no tienen esa tradición de movilidad, como la Huída a Egipto o la Matanza de los Inocentes. Algunos belenes antiguos incorporaban otras figuras en la

\footnotetext{
39 Ver A. CEA GUTIÉRREZ, "Del rito al teatro...", Actas de las jomadas sobre el Teatro popular en España (Biblioteca de Dialectología y Tradiciones Populares, XXII, C.S.I.C., Madrid, 1987), pp. 35 y 36, donde, además, se alude a otras tradiciones similares de movilidad de las imágenes.
} 
misma noche, como el grupo de Adán y Eva del monasterio de religiosas de Sineu, o la caída de nuestros primeros Padres en el de Inca, datos ambos que recoge Llompart ${ }^{40}$.

Otra característica de los belenes tradicionales españoles es la diferencia de escala. Mientras el belenismo moderno insiste en la perspectiva y la proporción rigurosa, junto a la unidad de acción que ya se observa en los belenes cortesanos, el mundo popular opta por una yuxtaposición de escalas, donde la talla mayor corresponde a los protagonistas del "misterio" que, sin embargo, ceden el primer plano a oferentes diminutos, que inmediatamente magnifican, por contraste, las figuras sacras, al modo de la escultura egipcia monumental. Se supone que este efecto es buscado ex-profeso y que nace, como otras manifestaciones populares, fruto de otro tipo de lenguaje que nada tiene que ver con las reglas académicas, pero que no por ello es menos riguroso y eficaz. La fabricación de figuras a escala, especialmente en Olot y Murcia, desde finales del siglo xvill, ha ido sustituyendo esta peculiaridad por las reglas de la perspectiva común, y hoy, conjuntos belenísticos tan venerables como el del Hospital del Pozo Santo en Sevilla, o el de las teresas de Palma, corren el riesgo de ser "adecentados", si no lo han sido ya, con las figuras al uso.

\section{d) Actividades en torno al belén}

Pero no solamente están "vivas" las figuras en los Nacimientos españoles, sino que, además, se desarrollan en torno al belén una serie de acontecimientos, que se pueden dividir en dos clases: ritos de expectación y ritos de celebración. Los primeros incluyen todo tipo de novenas, tales como el "Novenario de la expectación del parto de la Virgen Nuestra Señora..." ${ }^{41}$, oraciones especiales, canastillas espirituales ${ }^{42}$, preces místicas, mortificaciones

40 Ver G. Llompart, "Belenes conventuales mallorquines de los siglos XVII y xVIII", R.D.T.P., XXVI (1970), pp. 61-62. Creemos que pudo tener el mismo uso un grupo escultórico similar en su concepción al que publica LLOMPART, de $19 \mathrm{cms}$ de alto, atribuído a Melchor Díez (s. XVI),perteneciente a la Colegiata de Toro (Zamora). J. NAvarro TALEGÓN realiza un extenso comentario de dicha pieza en el catálogo de la exposición Las Edades del Hombre (Salamanca, 1988). Ver pp. 40-41.

41 a...que se hace cada año en la iglesia del Monasterio de Religiosas Capuchinas de la Ciudad de Palman, novenario impreso en 1724, citado por LLOMPART, op. cit., p. 63.

42 José CONTRERAS RODRíguez-JuRADO, describe así esta antigua costumbre, según la realizan las monjas Cistercienses de San Clemente de Sevilla: -... las monjas van elaborando durante el Adviento una canastilla espiritual para el Niño Dios. Para ello se sortean unas tarjetas o papelitos donde aparece escrito, junto a una máxima del tiempo, el nombre de una prenda del ajuar infantil, que se corresponde con una privación o sacri- 
monjiles e ingenuas representaciones, como las jornaditas, extendidas por la América Hispana, especialmente California y México, y, hasta hace muy poco, de uso general en Andalucía, sobre todo en la provincia de Sevilla ${ }^{43}$. Muchas de estas celebraciones preparatorias están vinculadas al ya citado culto de las clarisas al Niño Jesús Durmiente, que ha de revivir con el calor de nuestras almas, despertar que tendrá lugar la Noche de Navidad. Los rituales de celebración consisten principalmente en las llamadas ofrendas, que admiten dos categorías: físicas y espirituales. De las primeras, se recogen, a largo de toda la Península e islas, tradiciones conventuales de ofrecer los dulces artesanales de elaboración propia, a veces miniaturiazados ${ }^{44}$. Es tambien usual la presentación de panes realizados ex profeso, como els pans de corriola mallorquines ${ }^{45}$, mientras que la ofrenda de cítricos y los famosos barquillos

ficio..... En el mismo monasterio se conserva un célebre Misterio, realizado por Gómez de Maza, escultor del s. XviII, según las indicaciones de la visión que tuvo la "Madre Currita* en las escaleras del edificio. Ver, del autor citado «Navidad y vida monástica sevillana", $E l$ Belén en Sevilla (Sevilla, 1981), pp. 12-13.

43 Comienzan el 16 de diciembre, y consisten, básicamente, en una meditación colectiva sobre los avatares de los Santos Esposos en su viaje de empadronamiento. Son de rigor las imágenes de José y María con atuendo de "peregrinos" o caminantes. Véase al respecto el comentario de J. M. GOMEZ SÁNCHEZ, "El adviento y las Jornaditas", El Belén en Sevilla (Sevilla, 1981), pp. 5-6.

4t Ver CONTRERAS Rodríguez-Jurado, op. cit. Entre todas estas tradiciones, la que se lleva la palma es, sin duda, la del convento sevillano de franciscanas de Santa Inés, quienes, además de ofrendar quesos, bollería u otros productos a escala, en una diminuta tacita con su platillo, preparan un café bien cargado para San José, para que pueda velar esa noche.

45 LLOMPART, en diferentes artículos publicados en la ya citada Revista de Dialectología $y$ Tradiciones Populares, recoge las diferentes ofrendas que se realizan en los conventos de su tierra: -Ofrendas físicas: alimentos, fruta, dulces: "madrichos", "corbatetes", "rollos", "coques", XXVI (1970), p. 55. "neules" o barquillos, hoy papel recortado. Panes: como los que entregan los patronos, por ej. la familia Zaforteza, patronos del belén de la Concepción, R.D.T.P., XXVI (1970), p. 47; "presentallesn: vestidos, joyas, R.D.T.P., XIX (1963), pp. 368-369, en 1733: "Una maneta de cristall ad randeta d'or circuida"). Capones blancos, un par, a las capuchinas, R.D.T.P., XXVI (1970), p. 51. Espirituales: Votos,en la Epifanía: ante el belén de la Concepción, R.D.T.P., XXVI (1970) p. 47. Novena de las Teresas, para *...que nazca el niño en el propio corazón. "Sacra lotería de los patronos, el primero de año, R.D.T.P., XXVI (1970), p. 51. Y, por último, regalos de los conventos a sus patronos y bienhechores, como sles coques ensucrades" y otros dulces. R.D.T.P., XXVI (1970), p. 57, citando a A. Pol, comenta: -...Antiguamente el belén de Jesús, decano de los belenes mallorquines, se adornaba enristrando del cuello y astas de los corderos que orlan la gruta, docenas y docenas de mandarinas y manzanas, mientras que, en el cuello de los pastores y en la pierna en alto del gaitero, se colgaban grandes rollos, amontonándose además al pie pesados panes dobles, conocidos popularmente por pans de corriola. En Navidad, Año Nuevo y Reyes se ofrendaban grandes panes en otros conventos e iglesias de la isla, que 
de oblea o neules típicos parecen ser exclusivos de las Baleares. Las viejas tradiciones acerca de la sacralización del pan tienen también su aplicación la noche de Navidad ${ }^{46}$, y las ofrendas, a diferencia de otras, son repartidas entre la comunidad de los fieles, o bien se dejan, intactas, para decoración del Nacimiento. Otras ofrendas físicas pueden consistir en alimentos y animales diversos, vestimentas, joyería y exornos para las figuras del belén. Las ofrendas espirituales" tienen su núcleo en diferentes costumbres monjiles que suelen estar vinculadas a la devoción del Niño Jesús: o bien la priora se muestra con este en brazos, como en las Carmelitas de Santa Ana de Sevilla, o bien recorre la comunidad las celdas cantando a cada una de las imágenes infantiles que veneran las monjas, como sucede en Santa Paula, monasterio jerónimo, también de Sevilla ${ }^{47}$. Algunas de estas ofrendas, especialmente la renovación de los votos, se desplazan a la fiesta de la Epifanía, acompañando los dones de los Reyes Magos. La música aporta sus particularidades en las distintas zonas del país, desde los campanilleros andaluces a las rondas castellanas, con buesillos, panderetas, botella, cucharas,etc; se interpretan loas y villancicos, cantos como el de ala Sibilan, voces en coro y solistas; música y canciones todas que, fuera de la festividad, es de mal agüero repetir. Y, por último, el teatro, origen probable del fenómeno que estudiamos. Títeres, como los de .Tirisiti. de Alcoy, Autos de Navidad, belenes vivientes, con o sin diálogos, pastoradas, .funciones de Reyes", y otras escenificaciones, sobreviven repartidas por toda España, país que ha producido el que hasta la fecha se tiene como Auto de Reyes Magos más antiguo de la Cristiandad.

\section{CONCLUSIONES}

Nuestro análisis, necesariamente superficial ante un tema tan extenso, pretende demostrar, en primer lugar que son muy escasos los trabajos acerca

se repartian en la Misa mayor. Este grupo de artículos, realizados por Llompart, de los que se extrae, por falta de espacio - una mínima muestra, posee un valor singular al haber tenido acceso el autor a conventos de clausura donde ha recogido datos inéditos que, posteriormente, ha sistematizado adecuadamente, por lo que sus trabajos, restringidos al área de las Baleares, son modelo a seguir en el resto de España.

46 Así, tenemos unas curiosas galletas cenceñas, "casques", similares a la "matzá. hebraica, que se cuelgan como adomo en Luchmayor y que adquieren la cualidad de

- pan bendito por este único hecho, como también están benditos los roscos de pan que se ensartan en los brazos de las figuras pastoriles del "Betlem d'es Jesús" y en los cuernos de los carneros. Estos roscos son asimismo similares a las spicas" que se ensartan en los brazos de la Virgen y el Niño de La Alberca. LLOMPART, R.D.T.P., XXVI (1970), p. 58; CEA, op. cit., pp. 129-130 e il. en p. 38. Ambos ejemplos tienen un interés especial, por corresponder a zonas ricas en tradiciones fosilizadas, cuyos testigos permiten suponer un uso general y una expansión mayor de tales costumbres.

47 Ver CONTRERAS RODRIGUEZ-JURADO, op. cit., p. 14. 
de los Nacimientos españoles que tengan en cuenta todos sus aspectos, sin limitarse al estudio de sus elementos visibles (figuras, escenografía), aislándolos del contexto y relaciones con el mundo religioso institucional y la devoción popular.

En segundo lugar, la falta de un encuadre correcto lleva a entresacar estos elementos, despreciando el fenómeno en el que están ubicados, causa principal de la carencia actual de datos que, si se hubieran recogido desde, al menos, el siglo pasado, permitirían reconstruír con mucha más fidelidad de la que podamos tener hoy, el valor y uso exacto de esta costumbre en nuestro país.

Como se apuntó más arriba, la falta de conexión interdisciplinar que padece parte de la metodología propuesta para la investigación, especialmente en el campo de la Historia del Arte, hace que la interpretación de los testimonios materiales del pasado se reduzcan a una apreciación estética de acuerdo con las normas de corrección académica occidental que, con buena voluntad, han incorporado a su ideario la Asociaciones de Belenistas, únicas agrupaciones que se interesan por el fenómeno belenístico en conjunto, pero que proponen un modelo no tradicional de continuación.

Por tanto, este planteamiento inicial (en ninguna manera cerrado) pretende alertar de esta situación y atraer estudiosos y trabajadores de campo para que, al igual que han sido recogidas y estudiadas las manifestaciones teatrales o musicales de este ciclo litúrgico, no olviden el fenómeno belenístico, de arraigo y antigüedad diferente en las distintas zonas de España.

El asunto, como planteábamos al principio, se convierte en un tema grave, pues es grande el riesgo de perder, por falta de interés, los últimos datos que nos proporcionen los pocos belenes supervivientes, ya que se ven amenazados cotidianamente por una "racionalización" que acabará, tarde o temprano, borrando las huellas de su tradición.

En resumen, creemos que aquella escenificación navideña que no admite ninguna modificación ni genera ningún tipo de actividad de expectación o celebración, no puede propiamente, y en un sentido antropológico, denominarse belén o Nacimiento, como sucede con los llamados dioramas que, como vimos al principio, son el modelo de perfección propuesto por las Asociaciones de Belenistas. Sin embargo, y en contraposición, un belén monástico, aún intocado y conservado en un armario o en un escaparate, será siempre el eje de una intensa vivencia espiritual.

\author{
LETIZIA ARBETETA MIRA \\ Museo Nacional de Artes Decorativas \\ Madrid
}


El presente artículo trata la costumbre tradicional espanola (común a todo el ámbito católico) de representar plásticamente el Nacimiento de Cristo, mediante los llamados "Nacimientos". Normas del autodenominado "buen gusto" han sustituido casi por completo su presentación tradicional, simbólica, por una aproximación realista. Se recuerda la necesidad de estudiar el fenómeno desde una óptica multidisciplinar, con validez científica, en la que se contemple el conjunto sin separar, como suele hacerse, ninguno de sus elementos, especialmente los materiales que poseen valor artístico. El trabajo consta de tres partes: 1) un análisis de la situación actual, con los problemas principales para el tratamiento de una tradición a punto de perderse por sustitución; 2) el esquema del método que se propone; y 3) una primera delimitación de los personajes y entorno, además de algunas características de los "nacimientos" españoles.

In this article we are dealing about the spanish tradition (wich is also extensive to the whole Catholic environement) of the plastic representation of Crist Birth in the so called "Nacimientos". Now, the rules of "the good tast" have substitued the simbolic, traditional representation for an realistic aproximation. We sugest the convenience of a scientific and multidisciplinar study of the whole fenomena, without the separation of any of its elements (specially if they have artistic value) before the faiting of this singular and interesting tradition. There are three parts in this work: 1) the study of the actual situation, dealing with the major problems to avoid the extintion or substitution of this tradition; 2) the lines of the proposed methodology; and 3) the delimitation of the general environement and figures with some caracteristics of the Spanish "Nacimientos". 